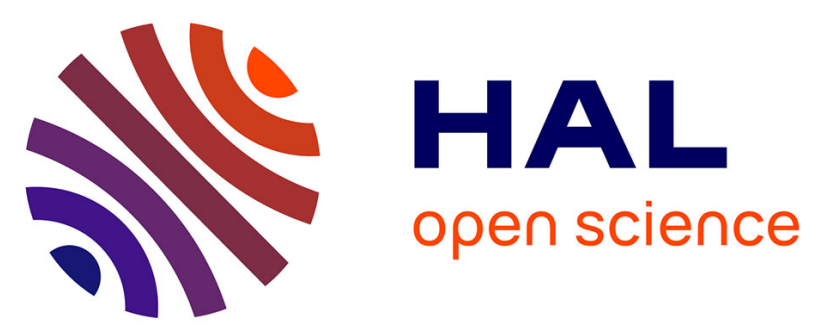

\title{
Full Organic Aqueous Battery Based on TEMPO Small Molecule with Millimeter-Thick Electrodes
}

Sofia Perticarari, Elodie Grange, Tom Doizy, Yann Pellegrin, Eric Quarez, Kenichi Oyaizu, Antonio Jesus Fernandez-Ropero, Dominique Guyomard, Philippe Poizot, Fabrice Odobel, et al.

\section{To cite this version:}

Sofia Perticarari, Elodie Grange, Tom Doizy, Yann Pellegrin, Eric Quarez, et al.. Full Organic Aqueous Battery Based on TEMPO Small Molecule with Millimeter-Thick Electrodes. Chemistry of Materials, 2018, 31 (6), pp.1869-1880. 10.1021/acs.chemmater.8b03282 . hal-02106760

\section{HAL Id: hal-02106760 https://hal.science/hal-02106760}

Submitted on 19 Nov 2020

HAL is a multi-disciplinary open access archive for the deposit and dissemination of scientific research documents, whether they are published or not. The documents may come from teaching and research institutions in France or abroad, or from public or private research centers.
L'archive ouverte pluridisciplinaire HAL, est destinée au dépôt et à la diffusion de documents scientifiques de niveau recherche, publiés ou non, émanant des établissements d'enseignement et de recherche français ou étrangers, des laboratoires publics ou privés. 


\title{
Full organic aqueous battery based on TEMPO small molecule with millimeter thick electrodes
}

\author{
Sofia Perticarari ${ }^{\dagger \ddagger}$, Elodie Grange ${ }^{\dagger}$, Tom Doizy ${ }^{\dagger}$, Yann Pellegrin ${ }^{\ddagger}$, Eric Quarez ${ }^{\dagger}$, Kenichi Oyaizu ${ }^{\xi}$, \\ Antonio Jesus Fernandez ${ }^{\dagger}$, Dominique Guyomard ${ }^{\dagger}$, Philippe Poizot†, Fabrice Odobel*‡, Joël \\ Gaubicher*† \\ †Institut des Matériaux Jean Rouxel (IMN), Université de Nantes, CNRS, 2 rue de la Houssinière, B.P. 32229, 44322 \\ Nantes Cedex 3, France. \\ ‡CEISAM, Chimie et Interdisciplinarité, Synthèse, Analyse, Modélisation, Université de Nantes, 2 rue de la Houssi- \\ nière, B.P. 92208, 44322 Nantes Cedex 3, France. \\ 'Department of Applied Chemistry, Waseda University, Tokyo 169-8555, Japan.
}

\begin{abstract}
Thick electrodes with sodium and even anions intercalation organic compounds integrated in a neutral-pH aqueous battery offer unique advantages in terms of round trip efficiency, environmental impact, and scalability for off or in-grid renewable energy storage. Herein we report on the first anion-rocking chair / dual-ion organic battery. The latter reaches $35 \mathrm{Wh} / \mathrm{kg}_{\text {materials }}$ at $\mathrm{C} / 8$ rate. It shows remarkable cyclability and Coulombic efficiency in a cheap and neutral $\mathrm{NaClO}_{4}$ electrolyte pouch cell with highly loaded millimeter thick electrodes $\left(5 \mathrm{mAh} / \mathrm{cm}^{2}\right)$. This achievement is based on a thorough study of a commercial benzene TEMPO compound (4-hydroxy TEMPO benzoate) and its naphthalene derivative (4-carboxy TEMPO naphthalate) as cathode materials, and a bipyridinium-naphthalene oligomer as the anode. Combined UV-vis spectroelectrochemistry and operando XRD account for the much improved cyclability of the hydrophobic 4-carboxy TEMPO naphthalate at the expense of a lower specific capacity. This trend is reversed in the case of the 4-hydroxy TEMPO benzoate derivative. Results show kinetic limitations of the 4-hydroxy TEMPO benzoate are associated with the surrounding composite electrode, while inner-grain ionic and/or electronic transports play a decisive role for the 4-carboxy TEMPO naphthalate.
\end{abstract}

\section{Introduction}

Aqueous batteries constitute a novel and promising technology towards renewable energy storage as they are inherently safe, minimize cost and environmental impact by comparison to other battery technologies ${ }^{1-4}$, thus offering a low cost and greener alternative to Li-ion systems. This approach is still affiliated however, with energy densities below $50 \mathrm{Wh} / \mathrm{kg}_{\text {cell }}$. Furthermore, the relatively narrow electrochemical window available in aqueous media together with costs and abundance issues makes even more challenging the development of appropriate materials. The latter should possess optimal potential as well as high chemical and electrochemical stability. As a result, the choice of greener and more abundant organic materials appear as a logical step. So far only two families of organic compounds have been demonstrating encouraging performance as positive electrode active materials in aqueous media: i) the p-type conjugated tertiary amine PTPAm showing interesting experimental capacity and good cyclability in $21 \mathrm{M} \mathrm{LiTFSI}$ water-in-salt electrolytes and ii) the nitroxyl radicals, more precisely the 2,2,6,6-tetramethylpiperidinyl-N-oxyl (TEMPO) derivatives. The latter is the most studied p-type redox systems in aqueous electrolyte ${ }^{6-}$ ${ }^{11}$. TEMPO undergoes a one electron oxidation process to give the oxoammonium cation, the charge being counterbalanced by the uptake of one anion from the electrolyte (Figure 1).

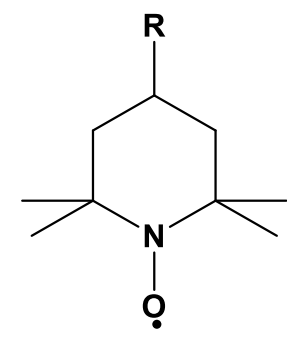

Nitroxyl radical

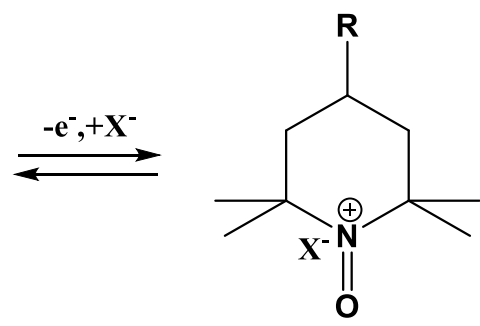

Oxoammonium salt
Figure 1. Schematic representation of the redox reaction of TEMPO derivatives.

Up to now, TEMPO derivatives in aqueous batteries have been mainly developed in the form of radical polymers. In this regard, Oyaizu and Nishide's group have demonstrated that the achievement of high molecular weight and proper volume swell ratio is fundamental for the good performance of the polymer ${ }^{12}$. They extensively investigated TEMPO's derivatives ${ }^{6-10,12,13}$, highlighting the difficulties in obtaining proper water compatible TEMPO polymer. As a 
result, the poly(2,2,6,6-tetramethylpiperidinyloxy-4-yl acrylamide) (referred to as PTAm) revealed the most interesting performance, enabling the development of two anionic rocking chair batteries. Noteworthy, until recently, electrodes were based on thin films of these polymers (from $50 \mathrm{~nm}$ to $3.2 \mu \mathrm{m})^{12}$. However, because low cost $(\leq \$ 100$ $\left.\mathrm{kWh}_{\text {installed }}{ }^{-1}\right)$ is a sine qua non condition to insure the economic viability of electrochemical systems for grid storage, aqueous batteries need to be built with ultra-thick $(>\mathrm{mm})$ electrodes. In this context, the same group has recently proposed thick composite electrodes of $3 \mathrm{mAh} / \mathrm{cm}^{2}$ by hybridizing PTAm with a $3 \mathrm{D}$ self-assembled mesh of singlewalled carbon nanotubes (SWCNT) ${ }^{7}$. Even though the cost of SWCNT can potentially be an issue, impressive performance have been obtained with only 1 to $5 \mathrm{wt} . \%$ SWCNT. Although all these approaches are effective in that they successfully convey organic materials with interesting performance as positive electrode material for neutral aqueous battery, a full cell with thick organic based electrodes of several $\mathrm{mAh} / \mathrm{cm}^{2}$ still remain to be demonstrated to the best of our knowledge. A different approach is proposed in the present work based on "small TEMPO molecules", rather than polymeric structures. We note that an example has been recently reported in the field of supercapacitor by Itoi et al. who adsorbed the HTB (1-Piperidinyloxy,2,2,6,6-tetramethyl-4-(2-oxo-2-phenylethyl)) in the mesoporosity of active carbon $(\mathrm{AC})^{14}$. Thanks to the huge contact area between the finely dispersed HTB molecules and the conductive AC surface, fast redox reactions of HTB could be achieved in aqueous $1 \mathrm{M} \mathrm{H}_{2} \mathrm{SO}_{4}$. Moreover, the strong adsorption capability of AC counteracts the dissolution of HTB in the electrolyte. On the contrary, it is worth pointing out that this method is inherently restricted to the supercapacitor field because of the high loading of conductive agent. The best performance ( $81 \%$ of capacity retention after 2000 cycles at $1 \mathrm{~A} / \mathrm{g}$ ) were typically obtained with $70 \mathrm{wt} . \%$ AC. Importantly, this kind of strategy, that is well known especially in the Li-S battery field since the work of Nazarr ${ }^{15}$, can only mitigate dissolution but not suppress it. Here we report on two different strategies that have been followed with the aim to produce a low cost and safe aqueous battery including p-type "small TEMPO molecules". Our approach will be supported by in-depth study of electrochemical behaviors as well as demonstration of potentialities and limitations of some of these materials in full cells of up to $5 \mathrm{mAh} / \mathrm{cm}^{2}$ using a new bipyridinium-naphthalene diimide oligomer as the negative electrode.

\section{Experimental section}

General procedure for the synthesis of TEMPO-bearing derivatives (note that all characterizations relative to synthesis of materials including, ${ }_{1} \mathrm{H}$ NMR, FTIR, TGA/DSC and XRD are reported at the end of the supplementary information file (Figure $\mathrm{S}_{20}$ to $\mathrm{S}_{42}$ ) to facilitate the reading of the article):
All commercially obtained solvents and reagents were used without further purification unless noted below. 1-Ethyl-3(3-dimethylaminopropyl)carbodiimide (EDC), 4-Dimethylaminopyridine (DMAP), 4-hydroxyTEMPO benzoate, 4-carboxyTEMPO, 4-hydroxyTEMPO, phenol, 2-hydroxynaphathalene, benzoic acid and 2-naphthalic acid were purchased from Sigma Aldrich. The PTAm polymer has been prepared and supplied by Nishide and Oyaizu's group.

Synthesis procedure of ${ }_{4} \mathrm{CTs}$ (4-carboxyTEMPO derivatives):

To a stirred solution of 4-carboxyTEMPO (1 eq.) DMAP (o.3 eq.) and the corresponding alcohol (o.7 eq) in dichloromethane cooled to $0^{\circ} \mathrm{C}$ in an ice bath, was added EDC ( $1 \mathrm{eq}$ ), and the mixture was warmed to ambient temperature over several hours and stirred for 48-72 h, following the reaction advancement through thin layer chromatography. The solution was diluted with dichloromethane and was washed with water $(2 \mathrm{x})$, a saturated aqueous solution of sodium bicarbonate (1x), and brine (1x). The organic layer was dried over sodium sulfate, concentrated in vacuum and purified by silica gel column chromatography to afford the compounds as an orange powder.

4CT-Benzene: (yield 75\%) ${ }^{1} \mathrm{H}$ NMR (30o MHz, DMSO-d6) $\delta 7.36-7.47(\mathrm{~m}, 3 \mathrm{H}), 7.21-7.29(\mathrm{~m}, 2 \mathrm{H}), 2.95(\mathrm{tt}, \mathrm{J}=12.9$ $\mathrm{Hz}, 1 \mathrm{H}) 1.96-1.97(\mathrm{~m}, 2 \mathrm{H}), 1.58(\mathrm{t}, \mathrm{J}=12.8 \mathrm{~Hz}, 2 \mathrm{H}), 1.12(\mathrm{~s}$, $6 \mathrm{H}), 1.09(\mathrm{~s}, 6 \mathrm{H})$. HRMS $(\mathrm{ESI})^{+} \mathrm{m} / \mathrm{z}$ calculated for $\mathrm{C}_{16} \mathrm{H}_{22} \mathrm{NO}_{3} \mathrm{Na} 299.1497[\mathrm{M}+\mathrm{Na}]^{+}$found 299.1503 . FT-IR $\left(\mathrm{cm}^{-}\right.$ $\left.{ }^{1}\right)$ : 2830-3000 (rocking $\left.\mathrm{CH}_{2}\right), 1744(\mathrm{C}=\mathrm{O}$ ester), $1366(\mathrm{~N}-\mathrm{O}$ stretch).

4CT-Napthalene: (yield 80\%) ' $\mathrm{H}$ NMR (300 MHz, DMSOd6) $\delta 7.94$ (ddd, J = 12.1, 8.9, $\left.5.9 \mathrm{~Hz},{ }_{3} \mathrm{H}\right), 7.67(\mathrm{~d}, \mathrm{~J}=2.4 \mathrm{~Hz}$, $1 \mathrm{H}), 7.55(\mathrm{qd}, \mathrm{J}=5.1,1.8 \mathrm{~Hz}, 2 \mathrm{H}), 7.31(\mathrm{dd}, \mathrm{J}=8.9,2.4 \mathrm{~Hz}$, $1 \mathrm{H}), 3.02(\mathrm{tt}, \mathrm{J}=12.8,3.4 \mathrm{~Hz}, 1 \mathrm{H}), 2.06-1.87(\mathrm{~m}, 2 \mathrm{H}), 1.62(\mathrm{t}$, $\mathrm{J}=12.8 \mathrm{~Hz}, 2 \mathrm{H}), 1.14(\mathrm{~s}, 6 \mathrm{H}), 1.11(\mathrm{~s}, 6 \mathrm{H})$. HRMS $(\mathrm{ESI})^{+} \mathrm{m} / \mathrm{z}$ calculated for $\mathrm{C}_{20} \mathrm{H}_{24} \mathrm{NO}_{3} \mathrm{Na} 349.1654[\mathrm{M}+\mathrm{Na}]^{+}$found 349.1658. FT-IR $\left(\mathrm{cm}^{-1}\right): 2760-3000$ (rocking $\left.\mathrm{CH}_{2}\right), 1744(\mathrm{C}=\mathrm{O}$ ester), 1366 (N-O stretch).

Synthesis procedure of $4 \mathrm{HTs}$ (4-hydroxyTEMPO derivatives):

To a stirred solution of 4-hydroxyTEMPO (1 eq.) DMAP (o.3 eq.) and the corresponding acid (o.7 eq) in dichloromethane cooled to $0^{\circ} \mathrm{C}$ in an ice bath, was added EDC (1 eq), and the mixture was warmed to ambient temperature over several hours and stirred for $48-72 \mathrm{~h}$, following the reaction advancement through thin layer chromatography. The solution was diluted with dichloromethane and was washed with water $(2 \mathrm{x})$, a saturated aqueous solution of sodium bicarbonate (1x), and brine (1x). The organic layer was dried over sodium sulfate, concentrated in vacuum and purified by silica gel column chromatography to afford the compound as a reddish powders. 
4HT-Benzene: (yield 53\%) ${ }^{1} \mathrm{H}$ NMR (300 MHz, DMSO-d6) $\delta 7.98-7.91(\mathrm{~m}, 2 \mathrm{H}), 7.75-7.61(\mathrm{~m}, 1 \mathrm{H}), 7.59-7.49(\mathrm{~m}$, $2 \mathrm{H}), 5.30-5.00(\mathrm{~m}, 1 \mathrm{H}), 1.98(\mathrm{ddd}, \mathrm{J}=11.3,4.3,1.7 \mathrm{~Hz}, 2 \mathrm{H})$, $1.61(\mathrm{t}, \mathrm{J}=11.7 \mathrm{~Hz}, 2 \mathrm{H}), 1.13(\mathrm{~s}, 12 \mathrm{H})$. HRMS $(\mathrm{ESI})^{+} \mathrm{m} / \mathrm{z}$ calculated for $\mathrm{C}_{16} \mathrm{H}_{22} \mathrm{NO}_{3} 276.1600[\mathrm{M}]^{+}$found 276.1603 . FT-IR $\left(\mathrm{cm}^{-1}\right)$ : 2834-3016 (rocking $\left.\mathrm{CH} 2\right), 1715$ ( $\mathrm{C}=\mathrm{O}$ ester), $1363(\mathrm{~N}-$ O. stretch).

4HT-Naphthalene: (yield 46\%) ' $\mathrm{H}$ NMR (300 MHz, DMSOd6) $\delta 8.67-8.55(\mathrm{~m}, 1 \mathrm{H}), 8.18-8.09(\mathrm{~m}, 1 \mathrm{H}), 8.08-7.91(\mathrm{~m}$, $3 \mathrm{H}), 7.74-7.58(\mathrm{~m}, 2 \mathrm{H}), 5.26(\mathrm{tt}, \mathrm{J}=11.2,4.2 \mathrm{~Hz}, 1 \mathrm{H}), 2.08-$ $1.99(\mathrm{~m}, 2 \mathrm{H}), 1.67(\mathrm{t}, \mathrm{J}=11.7 \mathrm{~Hz}, 2 \mathrm{H}), 1.15(\mathrm{~s}, 12 \mathrm{H})$. HRMS $(\mathrm{ESI})^{+} \mathrm{m} / \mathrm{z}$ calculated for $\mathrm{C}_{20} \mathrm{H}_{26} \mathrm{NO}_{3} 328.1913[\mathrm{M}+2 \mathrm{H}]^{2+}$ found 328.1916. FT-IR $\left(\mathrm{cm}^{-1}\right)$ : 2838-3016 (rocking $\mathrm{CH}_{2}$ ), 1712 ( $\mathrm{C}=\mathrm{O}$ ester), 1365 ( $\mathrm{N}-\mathrm{O} \cdot$ stretch).

Chemical oxidation of ${ }_{4} \mathrm{CT}$-Naphthalene:

The chemical oxidation of 4 CT-Napthtalene has been performed following the already reported procedure ${ }^{16}$. Glacial acetic acid $(2 \mathrm{~mL})$ and hydrogen peroxide $\left(5 \mathrm{~mL}, 29.0^{-}\right.$ $32.0 \%)$ was added to $1 \mathrm{M} \mathrm{NaClO}_{4}$ aqueous solution (100 $\mathrm{mL}$ ). The solution was added dropwise to the stirred ${ }_{4} \mathrm{CT}$-Naphthalene suspension in $1 \mathrm{M} \mathrm{NaClO}_{4}$ at ambient temperature. The mixture was left under vigorous stirring during 24 hours.

Characterization techniques:

${ }^{1} \mathrm{H}-\mathrm{NMR}$ spectra were acquired using a Bruker ARX 300 $\mathrm{MHz}$ spectrometer. Spectra were recorded at room temperature, chemical shifts are written in ppm, and coupling constant in Hz. Multiplicity is presented in the following way: $\mathrm{s}=$ singlet, $\mathrm{d}=$ doublet, $\mathrm{t}=$ triplet, $\mathrm{q}=$ quintuplet $\mathrm{m}=$ multiplet. High resolution mass spectrometry (HRMS) has been recorded on a XEVO G2-XS QTOF (Waters) operating on $\mathrm{ESI}^{+}$. Thermal analyses were performed with a NETZSCH STA 449F3 device under Argon atmosphere. Fourier transform infrared spectroscopy (FTIR) spectra were collected with a Bruker Vertex 70 device employing $\mathrm{KBr}$ pellets, using a DTGS detector at a resolution of $4 \mathrm{~cm}^{-}$ 1. Powder XRD diagrams have been recorded with the Bruker D8 Advanced system. X-ray single crystal diffraction data of 4 CT-Naphthalene were collected on an Agilent SuperNova diffractometer equipped with Atlas CCD detector and mirror monochromated microfocus $\mathrm{Cu}-\mathrm{K \alpha}$ radiation $(\lambda=1.54184 \AA)$. The structure was solved and refined on F2 by full-matrix least-squares techniques using SHELX programs. All non-hydrogen atoms were refined anisotropically and hydrogen atoms were placed in calculated positions. Multiscan empirical absorption was corrected using CrysAlisPro program (CrysAlisPro, Agilent Technologies, V1.171.37.35 g, 2014). Table S1 gives a summary of the crystallographic data and the structure refinement. Operando $\mathrm{X}$-ray diffraction patterns were recorded using a PANanalytical X'Pert Pro diffractometer operated in Bragg-Brentano reflection geometry with a Long Line Focus $\mathrm{Cu}$-anode $\mathrm{X}$-ray source, and a X'Celerator RTMS detector. Data were collected in a (10-30 $)^{\circ} 2 \theta$ range with a step of $0.033^{\circ}$ and an acquisition time of $5^{\prime} 16^{\prime \prime}$ per diagram. Measurements were performed with a Multi Purpose Sample Stage (MPSS) able to accommodate the in situ Swagelok-type cell. Note that the common beryllium window was removed because it was unstable in the tested electrochemical conditions. Therefore, we replaced the beryllium window by a thin Kapton ${ }^{\circledR}$ foil (X-ray film polyimide Kapton ${ }^{\circledast}$, PANalytical BV); thickness: $10 \mu \mathrm{m}$, diameter: $6.4 \mathrm{~mm}$. A threefold-size (in $\mathrm{mAh}$ ) carbon electrode (8o wt.\% activated carbon Norit 16oo, 10 wt.\% Ketjenblack (Kb) EC-6ooJD (AkzoNobel), and $10 \mathrm{wt} . \%$ polytetrafluoroethylene (PTFE)) was used as negative and reference electrode whereas the positive electrode composition was $70 \mathrm{wt} . \%$ of active material, $25 \mathrm{wt} . \%$ Ketjenblack EC-6ooJD, and 5 wt.\% PTFE. This mixture was pressed at 10 tons on a stainless steel (AISI 316L) grid current collector. Thick electrodes of ${ }_{4} \mathrm{HT}$-benzene and $\mathrm{DNVBr}$ were obtained pressing at 5 tons a $70 \mathrm{wt} \%$ active material, 25 wt $\%$ Ketjen Black, 5 wt $\%$ PTFE mixture into a pellet. The latter was then inserted in a specially designed mold and pressed at 2 tons between two stainless steel grids. Peak fitting was performed using Winplotr using a Gaussian function with constant FWHM defined by $\mathrm{U}=0.07^{\circ}$. UV-Vis spectroelectrochemistry was conducted by inserting a home-made three-electrode quartz cell into a Shimadzu UV-2501 PC spectrometer. Each scan was recorded from 250 to $800 \mathrm{~nm}$ within approx. $4 \mathrm{~min}$. Calibration curves were performed by dissolution of $4 \mathrm{HT}-\mathrm{Bz}$ in acetonitrile and $4 \mathrm{CT}$-Napht in Ethylacetate. Both these solvents show an absorbance cutoff below $270 \mathrm{~nm}$ which allows to follow the signal of the two compounds. Solutions of these compounds show the same color as in the solid state although being more pale as dissolution increases.

Electrochemical study:

The various electrochemical measurements were performed using $\mathrm{SP}_{300}, \mathrm{MPG}-2$ and $\mathrm{VMP}_{3}$ potentiostats from Bio-logic SAS (Claix, France). All the TEMPO derivatives have been characterized by galvanostatic cycling in aqueous $\mathrm{NaClO}_{4} 1 \mathrm{M}$ electrolyte. $4 \mathrm{HT}$-Benzene was also tested in highly concentrated aqueous electrolyte (8 M). Unless otherwise specified, the electrode composition is $70 \mathrm{wt} . \%$ active material, 25 wt.\% Ketjenblack, 5 wt.\% PTFE. The electrode mixtures have been prepared vigorously mixing the three components in the dry state with the use of a mortar. A co-precipitated mixture has been also prepared. The 4CT-Naphthalene (70 wt.\%) has been dissolved in the minimum volume of dimethylsulfoxide (DMSO) then 25 wt.\% Ketjenblack has been added to the solution. The suspension has been vigorously stirred during one hour. Subsequently, it has been added dropwise into a stirred water solution. The precipitate has been finally filtered, washed and dried at $60^{\circ} \mathrm{C}$ under vacuum overnight. $5 \mathrm{wt} . \%$ PTFE has been finally added mixing the powders in a mortar. Caution was taken in preparing thin electrodes with at 7 to $10 \mathrm{mg}$ of active material $/ \mathrm{cm}^{2}\left(0.7-1 \mathrm{mAh} / \mathrm{cm}^{2}\right)$ pressed at 5 tons on a stainless steel (AISI 316L) grid current collector. Thicker electrodes of $80 \mathrm{mg} / \mathrm{cm}^{2}$ were made in two steps. First a pellet was obtained by pressing at 5 tons the 
active material mixture. This pellet was then introduced between two stainless steel grids and pressed at 2 tons in order to favor the current collector-electrode mixture contacts. A threefold-oversized counter-electrode (8o wt.\% activated carbon Norit 160o, $10 \mathrm{wt} . \%$ Ketjenblack, and $10 \mathrm{wt} . \%$ PTFE) and a Saturated Calomel Electrode (SCE) as reference were used in all aqueous tests. Thick electrode full cells have been prepared based on $7.8 \mathrm{mAh} / \mathrm{cm}^{2}$ $\left(80 \mathrm{mg} / \mathrm{cm}^{2}, 1.09 \mathrm{~mm}\right.$ for 4 HT-benzene) and $8 \mathrm{mAh} / \mathrm{cm}^{2}$ $\left(80 \mathrm{mg} / \mathrm{cm}^{2}, 0.86 \mathrm{~mm}\right.$ for DNVBr$)$. All full cells tests were performed within an argon-filled glovebox with less than 1 ppm $\mathrm{O}_{2}$. An example of thick electrodes full cell has been also made using a pouch cell three electrodes configuration. Two microfiber glass separators were used, the first to isolate the positive $\left(81 \mathrm{mg} / \mathrm{cm}^{2}, 7.9 \mathrm{mAh} / \mathrm{cm}^{2}\right.$ for ${ }_{4} \mathrm{HT}$ benzene) and the negative electrode $\left(86 \mathrm{mg} / \mathrm{cm}^{2}\right.$, $9 \mathrm{mAh} / \mathrm{cm}^{2}$ for $\mathrm{DNVBr}$ ) and another between the negative and reference electrode. Pouch cells reference electrodes were composed of $\mathrm{Li}_{0.5} \mathrm{FePO}_{4}$. The cell used was an aluminum bag $(8 \mathrm{~cm} \times 5.5 \mathrm{~cm})$ from Sidec (model CA 40) sealed at $190^{\circ} \mathrm{C}$, where $1.5 \mathrm{~mL}$ of electrolyte $\left(8 \mathrm{M} \mathrm{NaClO}_{4}\right)$ have been added. The pouch cell has been prepared in an argonfilled glovebox and tested outside. Regular cyclic voltammetry experiments in solution have been conducted by dissolving $1 \mathrm{mM}$ of the four TEMPO derivatives in acetonitrile/ $/ \mathrm{NaClO}_{4} 2.5 \mathrm{M}$ as the electrolyte and recorded with a Pt micro disc electrode $(\varnothing=1.5 \mathrm{~mm})$. A large Pt wire has been used as counter electrode whereas the reference electrode consisted in a $\mathrm{Ag} / \mathrm{AgNO}_{3}\left(\mathrm{TBAClO}_{4} 10 \mathrm{mM}\right.$ in acetonitrile). The potential values reported in Figure 4 are versus an aqueous $\mathrm{SCE}\left(\mathrm{Ag} / \mathrm{AgNO}_{3}=+0.36 \mathrm{~V}\right.$ vs $\left.\mathrm{SCE}\right)$. The considered temperature of the cell was $25^{\circ} \mathrm{C}$. Electrochemical impedance measurements were performed from $180 \mathrm{kHz}$ to $100 \mathrm{mHz}$ with a perturbation voltage of $10 \mathrm{mV}$. Power tests have been carried out on discharge using the single discharge technique consisting of relaxation periods until $\Delta \mathrm{E} / \Delta \mathrm{t}=1 \mathrm{mV} / \mathrm{h}$ between each current pulse from $\mathrm{I}_{\max }$ to $I_{\min }$. All experiments were conducted twice in order to ensure reproducibility. Maximum experimental errors related to capacity values were kept below $5 \%$ using our protocols and set-up.

\section{Results and discussion}

Four TEMPO bearing redox active molecules have been investigated (Figure 2): the commercially available 4-hydroxy TEMPO benzoate (4HT-Benzene), the isomer 4-carboxy TEMPO benzoate and their naphthalene derivatives (4HT-Naphthalene and ${ }_{4} \mathrm{CT}$-Naphthalene). The last three compounds have been produced upon esterification reaction in order to obtain the benzoate or naphthalate ester in the 4-position of the piperidine ring. Importantly in regard to the targeted application, these compounds can readily be obtained in gram scales by a one pot reaction. The materials have been fully characterized by means of Electrospray ionization high-resolution mass spectrometry (ESI-HRMS), liquid nuclear magnetic resonance (NMR) and Fourier transform infrared (FT-IR) spectroscopies as well as thermal analyses (for further details see in supplementary information).

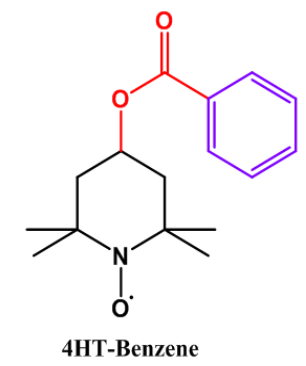

$Q$ theoretical $=96.99 \mathrm{mAh} / \mathrm{g}$

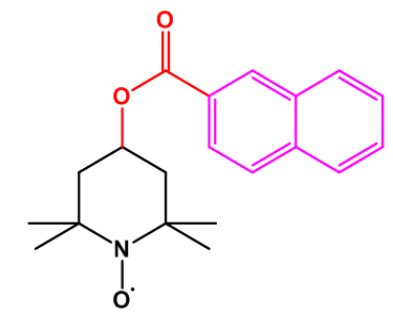

4HT-Naphthalene

$\mathrm{Q}$ theoretical $=82.12 \mathrm{mAh} / \mathrm{g}$

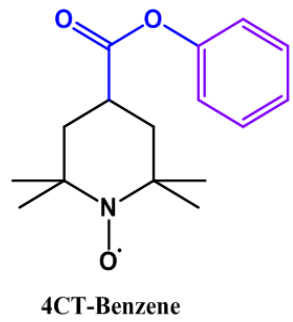

$Q$ theoretical $=96.99 \mathrm{mAh} / \mathrm{g}$

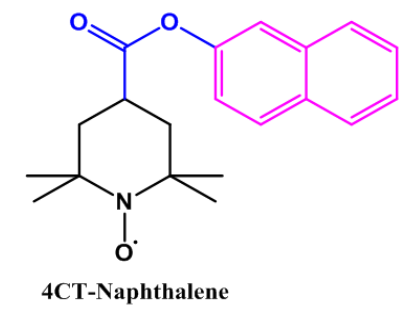

$Q$ theoretical $=82.12 \mathrm{mAh} / \mathrm{g}$
Figure 2. Molecular structure of the four TEMPO derivatives and their theoretical specific capacity.

Single crystals of the ${ }_{4} \mathrm{CT}$-Naphthalene compound could be obtained and its crystal structure compared to that of one of the two benzene derivative, the $4 \mathrm{HT}$-Benzene. X-ray single crystal structure data study reveals that $4 \mathrm{CT}$ Naphthalene crystallizes in the non-centrosymmetric $P_{21}$ space group and consists of $\mathrm{iD}$ supramolecular arrangements of molecules (Figure 3a). The $\mathrm{d}_{\mathrm{N}-\mathrm{O}}$ distance of 1.286(3) $\AA$ found in 4CT-Naphthalene is typical of a free radical single bond $\mathrm{N}-\mathrm{O} \cdot{ }^{\cdot 17}$. Moreover, the chair conformation of the piperidine ring clearly indicates that the nitrogen is in sp3 hybridization state confirming $\mathrm{N}-\mathrm{O}$ is a single bond. The organization of ${ }_{4} \mathrm{CT}$-Naphthalene radicals into $\mathrm{ID}$ chains is achieved via weak $\mathrm{C}-\mathrm{H} \cdots \mathrm{O}$ interactions between oxygen and hydrogen of the radical rings with a $\mathrm{N}-\mathrm{O} \cdot / \cdot \mathrm{O}-\mathrm{N}$ distance of 5.766(2) $\AA$ (Table 1 and Figure $3 \mathrm{~b}$ ). In the bc plane, $\mathrm{N}-\mathrm{O} \cdot / \cdot \mathrm{O}-\mathrm{N}$ distances are shorter than in 1D chains (5.259(3) Å). Comparing structural features of ${ }_{4} \mathrm{CT}$-Naphthalene with that of $4 \mathrm{HT}$-Benzene ${ }^{18}$ brings valuable information: $\mathrm{N}-\mathrm{O} \cdot / \cdot \mathrm{O}-\mathrm{N}$ distances in $4 \mathrm{HT}$-Benzene are not only longer, but an inversion also occurs as the shortest $\mathrm{N}-\mathrm{O} \cdot / \cdot \mathrm{O}-\mathrm{N}$ distances run along the $1 \mathrm{D}$ chains (6.128(7) $\AA$ ) whereas the longest distances are found in the bc plane (6.264(7)-6.287(6) ̊̊).

Table 1. Weak C-H...O interactions in ${ }_{4} \mathrm{CT}$ Naphthalene

\begin{tabular}{|c|c|c|c|c|}
\hline $\mathbf{C}-\mathbf{H} \cdots \mathbf{O}$ & $\begin{array}{c}\mathrm{C}-\mathbf{H} \\
(\AA)\end{array}$ & $\begin{array}{c}\mathbf{H} \cdots \mathbf{O} \\
(\AA)\end{array}$ & $\begin{array}{c}\mathbf{C} \cdots \mathbf{O} \\
(\AA)\end{array}$ & $\mathbf{C}-\mathbf{\mathrm { A }})$ \\
& $\mathbf{H} \cdots\left(^{\circ}\right)$ \\
\hline
\end{tabular}




\begin{tabular}{|c|c|c|c|c|}
\hline $\begin{array}{c}\mathbf{C}_{2}- \\
\mathbf{H}_{2} \mathbf{C} \cdots \mathbf{O}_{1}{ }^{\mathbf{i}}\end{array}$ & 0.96 & 2.62 & $3.553(3)$ & 163 \\
\hline $\begin{array}{c}\mathbf{C}_{5}- \\
\mathbf{H}_{5} \cdots \mathbf{O}_{1}{ }^{\mathbf{i}}\end{array}$ & 0.98 & 2.64 & $3.623(3)$ & 178 \\
\hline
\end{tabular}

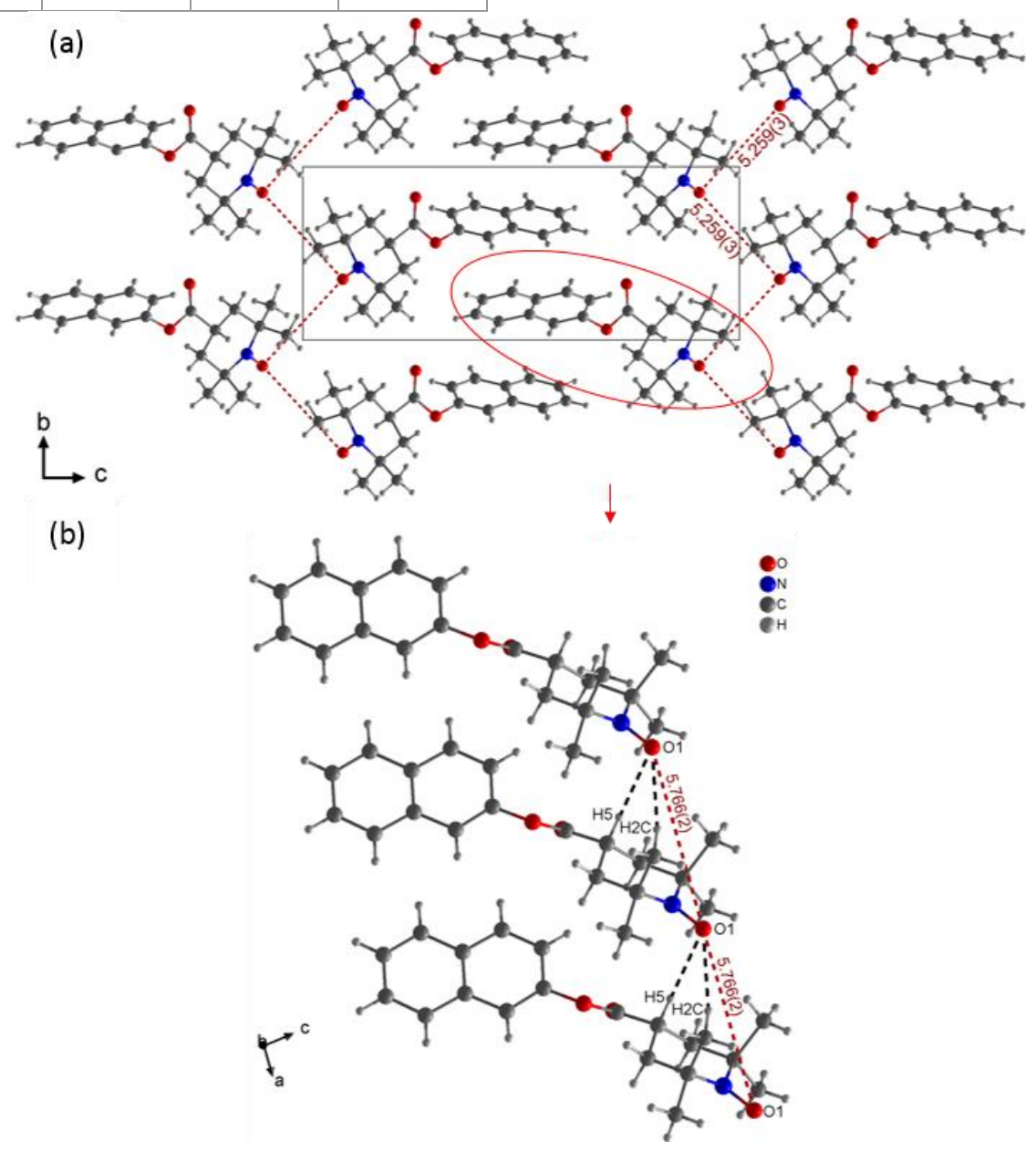

Figure 3. Structural features of 4 CT-Naphthalene a) Crystal packing and N-O--.O-N distance in the bc plane and b) N-O.-.O-N distance into $1 \mathrm{D}$ chains and weak $\mathrm{C}-\mathrm{H}$-..O interactions represented in dashed black line in ${ }_{4} \mathrm{CT}$-Naphthalene.

The electrochemical activity of the four materials has been firstly characterized by cyclic voltammetry in the solubilized state using acetonitrile/ $\mathrm{NaClO}_{4} 2.5 \mathrm{M}$ as the electrolyte (Figure $\mathrm{S} 1$ ). All derivatives exhibit a single reversible process with $\Delta \mathrm{Ep}$ approaching the reversible one electron value of $58 \mathrm{mV}$. The characteristic peak potentials on oxidation was not found to vary significantly indicating the substituent group has a weak inductive effect if any. Lastly, derivation of diffusion coefficients (Figure S2 and Table S2, see details in supplementary information) are all similar and comparable to the value reported for the 2,2,6,6-tetramethylpiperidinyl-N-oxyl (TEMPO) radical'3.

As shown by galvanostatic experiments, the electrochemical profile is strongly modified in the solid state with the occurrence of two electrochemical steps (Figure 4). This point is also illustrated using cyclic voltammetry for the two naphthalene compounds (Figure $\mathrm{S}_{3}$ ). The reaction starts on oxidation by a smooth increase of the incremental capacity (I) followed by a plateau type process (II). We note the capacitive contribution of the carbon additive (25 wt.\%) to the overall electrochemical response is negligible (Figure $\mathrm{S}_{4}$ ). The two benzene derivatives appear quite unstable in $1 \mathrm{M} \mathrm{NaClO}_{4}$ electrolyte showing an important capacity fade during cycling (Figure 5 ). 4 HT-Benzene in particular shows a continuous fading of $70 \%$ in 100 cycles $(123$ hours). Accordingly, UV-Vis analysis of the 4 HT-Benzene electrolyte upon 100 cycles clearly highlights the dissolution of the material (Figure $\mathrm{S}_{5}$ ). Interestingly, the introduc- 
tion of more hydrophobic naphthalene moiety significantly improves the cyclability at the expense of a lower specific capacity. In particular, the initial capacity of ${ }_{4} \mathrm{CT}$ Naphthalene isomer increases from $35 \mathrm{mAh} / \mathrm{g}$ up to to $44 \mathrm{mAh} / \mathrm{g}$ in 60 cycles followed by a capacity loss restricted to $4.5 \%$ during the following 40 cycles. Consequently, no color change could be detected in the electrolyte, while chemical oxidation with hydrogen peroxide did not result in any apparent dissolution of the compound (see Experimental part).
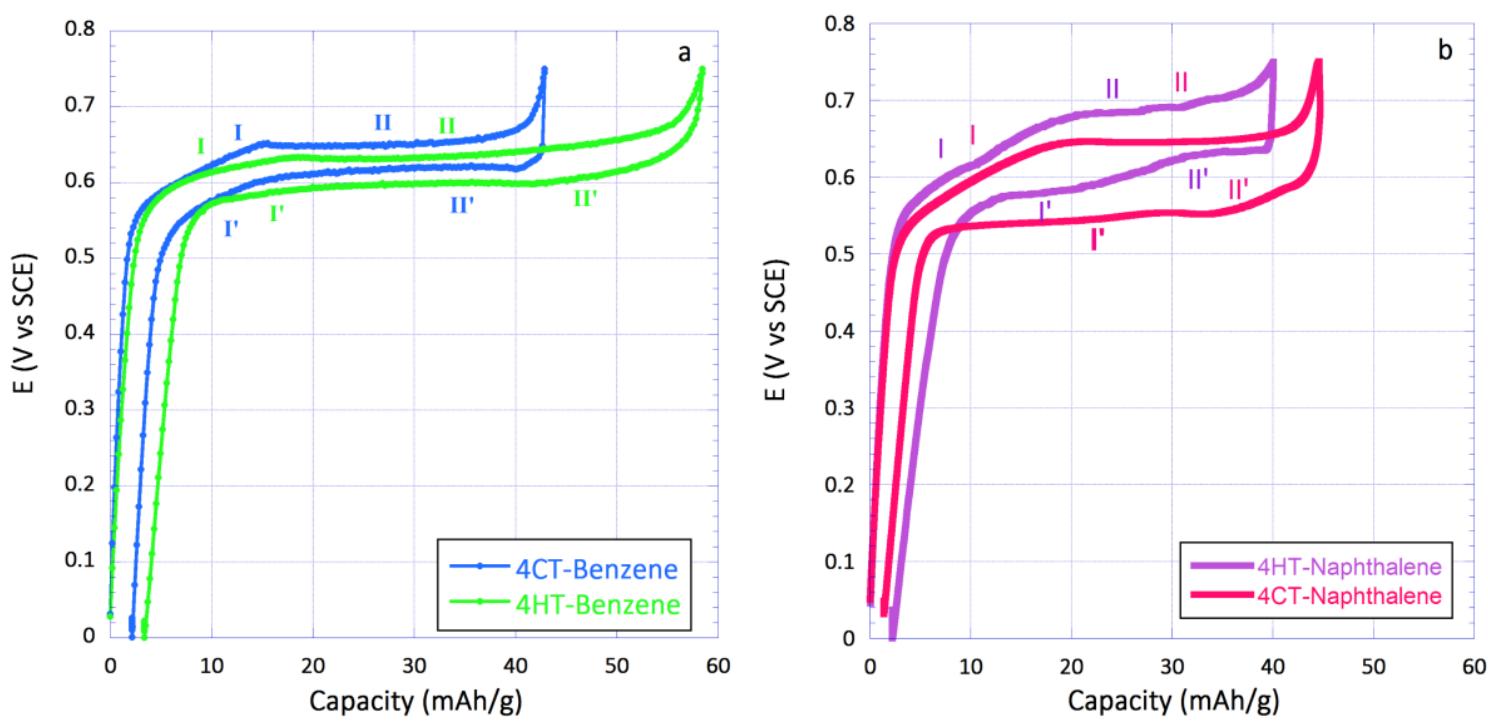

Figure 4. Galvanostatic curves for ${ }_{4} \mathrm{CT}$-Benzene (blue) on cycle $19,4 \mathrm{HT}$-Benzene (green) on cycle 1, $4 \mathrm{CT}$-Naphthalene (pink) on cycle 60 and $4 \mathrm{HT}$-Naphthalene (violet) on cycle 22 at $0.075 \mathrm{~A} / \mathrm{g}$ in $1 \mathrm{M} \mathrm{NaClO}_{4}$ aqueous electrolyte. Selected cycles correspond for each compound to the maximum capacity obtained during the first 100 cycles as shown on Figure 5 . Electrodes are in the vicinity of $0.7 \mathrm{mAh} / \mathrm{cm}^{2}$.

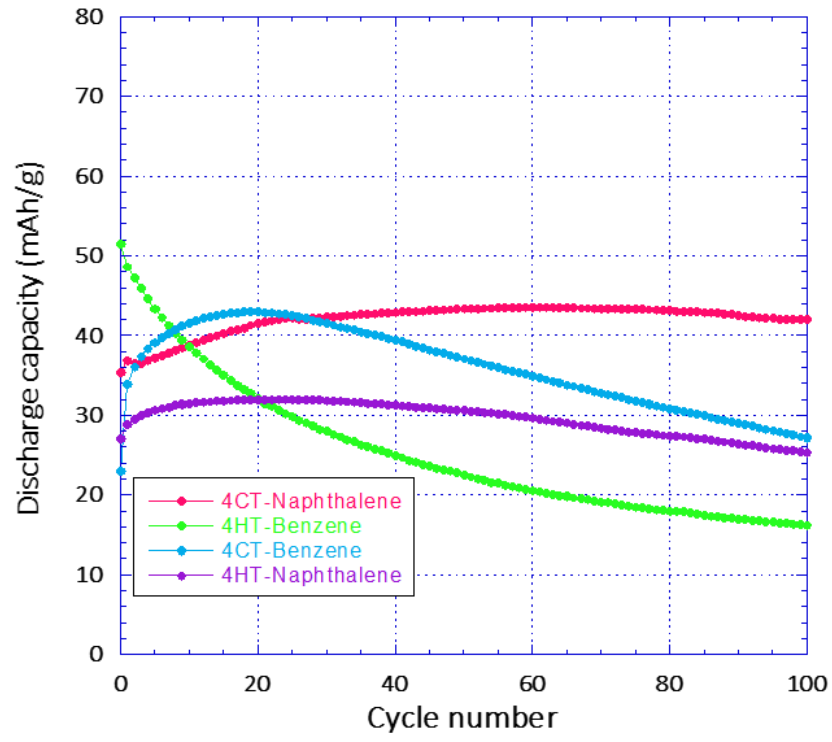

Figure 5. Cyclability curves for the four compounds in $1 \mathrm{M} \mathrm{NaClO}_{4}$ at $0.075 \mathrm{~A} / \mathrm{g}\left({ }_{4} \mathrm{CT}\right.$-Benzene (blue), ${ }_{4} \mathrm{HT}$-Benzene (green), $4 \mathrm{CT}$ Naphthalene (pink) and 4 HT-Naphthalene (violet)). Electrodes are in the vicinity of $0.7 \mathrm{mAh} / \mathrm{cm}^{2}$.

To get a better insight, UV-Vis spectroelectrochemistry has been performed during 158 hours while the sample was cycled at $0.075 \mathrm{~A} / \mathrm{g}$ (194 cycles) within the usual potential window of (o; o.75) V vs SCE. Simultaneously with the initial increase of capacity during the first 6o hours, a UV band appears at $300 \mathrm{~nm}$ (Figure 6). The latter rises during 
80 hours and stabilizes throughout the remaining cycles to $0.07 \mathrm{mM}$. This value corresponds in fact to a negligible part of the initial compound ( $5 \mathrm{wt} . \%$ ) (Figure S6). The question is now whether, this concentration corresponds to a solubility limit or alternatively, is limited because part of the active material does not participate in the electrochemical reaction. A first hint is given by the fact that irrespective of the electrolyte to active material mass ratio, $4 \mathrm{CT}$ Naphtalene always gives the same order of maximum spe- cific capacity ( $40 \pm 5 \mathrm{mAh} / \mathrm{g}, 52 \%$ of the theoretical capacity). Besides, there is no clue so far regarding the source of capacity limitation. In this goal the first issue to be addressed consist in determining if, as suggested above, some grains are poorly electrically connected, or alternatively if all grains react but the electrochemical reaction is thermodynamically limited because of overwhelming charge repulsion and/or lack of space to host ions within the oxidized host material.
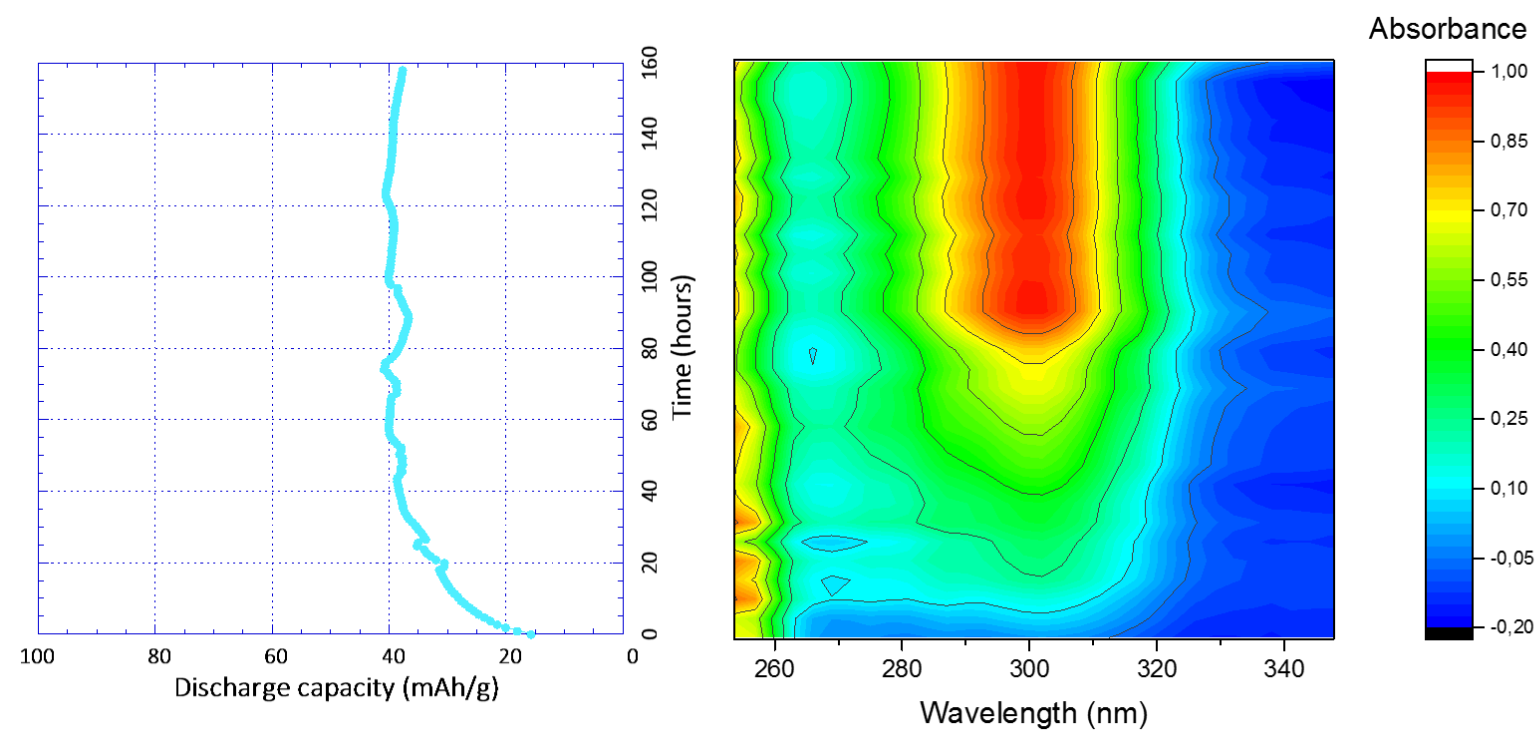

Figure 6. Operando UV-vis spectroelectrochemical spectra (right) and corresponding evolution of the discharge capacity of 4 CTNaphthalene upon cycling (left) measured at $0.075 \mathrm{~A} / \mathrm{g}$ in $1 \mathrm{M} \mathrm{NaClO}_{4}$ aqueous electrolyte and within (o; 0.75) V vs SCE potential window.Electrode is in the vicinity of $0.7 \mathrm{mAh} / \mathrm{cm}^{2}$.

To address this point, Operando XRD measurements of ${ }_{4}$ CT-Naphtalene have been performed during galvanostatic cycling. Noteworthy, each scan $\left(10-30^{\circ}\right)$ was $5^{\prime} 16^{\prime \prime}$ therefore enabling a reliable description of the structural behavior by approx. 24 scans for each charge or discharge. The compound has been first cycled within (-o.1; 0.95) V vs SCE. The corresponding overall structural evolution is given in Figures $7 \mathrm{a}$ for the first cycle (the first four cycles are shown in Figure $\mathrm{S}_{7}$ ). The initial phase (Po) is characterized in Figure $7 \mathrm{a}$ by three main peaks at $12.26^{\circ}, 13.61^{\circ}$ and $14.62^{\circ}$. During the first part of the charge $(\mathrm{o}<\mathrm{Q} / \mathrm{Qo}<15 \%$ or $0<$ Scan $<10$ ) the galvanostatic profile is characterized by a smooth variation of the voltage that corresponds to that observed for the potential in figure $4 \mathrm{~b}(\mathrm{o}<\mathrm{Q}<12 \mathrm{mAh} / \mathrm{g})$. Surprisingly however, no angular shift was detected for the initial set of peaks during the first $10^{\text {th }}$ scans ( 55 minutes, Figure S8). Instead, intensities were found to decrease at the expense of a new phase $(\mathrm{Pl})$ characterized by a set of growing reflections at constant angle $\left(15.22^{\circ}, 15.77^{\circ}, 19.49^{\circ}\right.$ and $24.17^{\circ}$ ) (Figure $7 \mathrm{a}$ and $\mathrm{S}_{7}$ ). Peak fittings allowed a quantitative description of the phase transformation progress referred to as $\xi_{\mathrm{i}}$ ((Figure $7 \mathrm{~b}$, pink curve). The latter was derived according to the ratio $\xi_{\mathrm{i}}=1-\left[\mathrm{I}(\mathrm{Po})_{\mathrm{i}} / \mathrm{I}(\mathrm{Po})_{\mathrm{o}}\right]$ where
$\mathrm{I}(\mathrm{Po})_{\circ}$ and $\mathrm{I}(\mathrm{Po})_{\mathrm{i}}$ are the sum of the integrated intensity of the three main peaks of ( $\mathrm{Po}$ ) listed above, at the beginning and, during the electrochemical cycling respectively. The evolution of $(\mathrm{P} 1)$ (Figure 8 b, violet curve) was tracked by the ratio between the integrated intensity $\mathrm{I}\left(\mathrm{P}_{1}\right)_{\mathrm{i}}$ of the $\left(\mathrm{P}_{1}\right)$ main peak at $15.22^{\circ}$ on cycle $\mathrm{i}$, over that obtained by extrapolation of $\mathrm{I}\left(\mathrm{P}_{1}\right) \mathrm{i}$ at $100 \%$ of the theoretical capacity, referred to as $\mathrm{I}\left(\mathrm{P}_{1}\right)_{\text {MAX }}$ (see Supplementary Information, Figure $\mathrm{S} 9$ ). Finally, the evolution of the specific capacity $Q_{n}$ normalized by the theoretical one $\mathrm{Q}_{\text {theoretical }}$ is also shown in Figure $8 \mathrm{~b}$ (for the sake of clarity, comparison of these curves vs the voltage is reported in supplementary information, Figure S1o). The trends of the structural and electrochemical evolutions probed by $\xi i$ and $Q_{n} / Q_{\text {theoretical }}$ generally fits well for the whole cycle and the similar slopes of 1$\left[\mathrm{I}(\mathrm{Po})_{\mathrm{i}} / \mathrm{I}(\mathrm{Po})_{\mathrm{o}}\right]$ and $\left.\mathrm{I}(\mathrm{P} 1)_{\mathrm{i}} / \mathrm{I}\left(\mathrm{P}_{1}\right)_{\mathrm{MAX}}\right)$ in shows $(\mathrm{Po})$ and $\left(\mathrm{P}_{1}\right)$ transforms into one another during the reaction. However, at the beginning of the charge and discharge the extent of the phase transformation is up to $10 \%$ below that expected by referring to the relative capacity $Q / Q_{0}$. This type of "structural delay" has been observed for the phase transformation between $\mathrm{LiFePO}_{4} / \mathrm{FePO}_{4}{ }^{19-22}$ due to inhomogeneities at the electrode scalezo. We note that on the first cycle 
the capacity on charge is $28.8 \%$ higher than on discharge while it is only $\mathbf{1 2 . 7 \%}$ higher on the second cycle (Figure S11). However, the amounts of $\mathrm{P} 1$ at the end of the $1^{\text {st }}$ and $2^{\text {nd }}$ charge are virtually unchanged (Figure S8) therefore demonstrating a significant participation of oxygen evolution to the Coulombic inefficiency (Figure S12). Importantly, results clearly show that a significant fraction of $(\mathrm{Po})(48 \%)$ does not react upon charge (Figure $7 \mathrm{~b})$. When the current is reversed, $88 \%$ of $(\mathrm{P} 1)$ transforms back to $(\mathrm{Po})$ which fits well with the recovered specific capacity of $41 \mathrm{mAh} / \mathrm{g}$. We note that the residual trace at the end of the reduction $(6 \%)$ of $(\mathrm{P} 1)$ suggests either kinetic

a

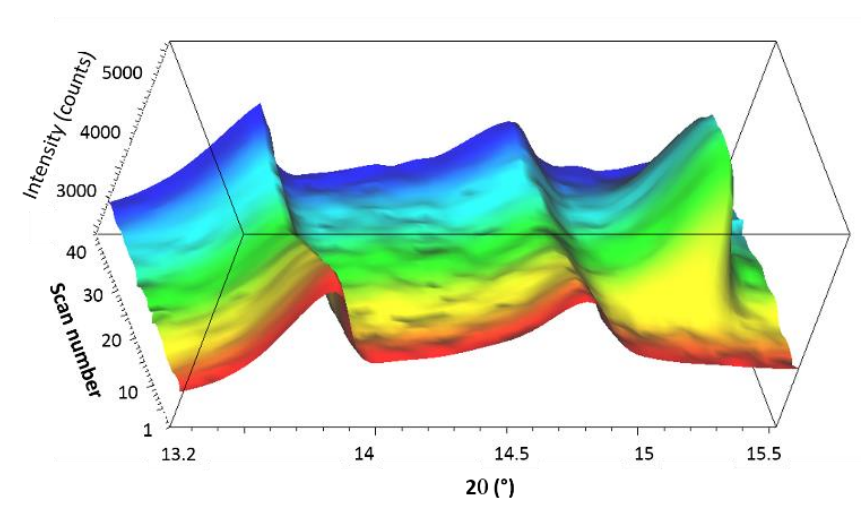

limitation and/or oxidation of (Po) by dissolved oxygen which was produced on charge.

In conclusion, based on a one electron reaction as proposed in Figure 1, operando XRD shows that the specific capacity of 4CT-Naphthalene scales with the mass ratio of matter that is involved in the electrochemical reaction. Accordingly, either some grains are not connected to the electrical circuit and/or the electrode highly suffers from kinetic hindrance causing some grains to partially react. This last hypothesis can primarily stem either from the efficiency of electronic percolation network within the composite electrode or, from the electrical conductivity of the compound itself (electronic and/or ionic).

b

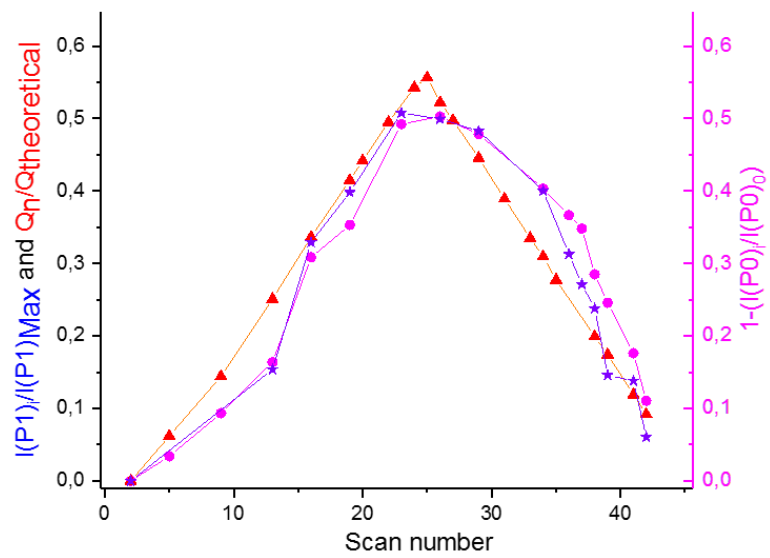

Figure 7. a) XRD diagrams collected for 4 CT-Naphtalene during the first cycle within (-o.1; 0.95) V vs SCE showing the phase transformation between the initial phase Po and the new phase P1 characterized by a peak at $15.22^{\circ}$. b) Evolution of the corresponding structural phase transformation derived by $\xi_{\mathrm{i}}=1-\left[\mathrm{I}(\mathrm{Po})_{\mathrm{i}} / \mathrm{I}(\mathrm{Po})_{\mathrm{o}}\right]$, ( $\left.\mathrm{Po}\right)$ being the initial phase, compared to the evolution of the fraction of the new phase $\left(\mathrm{P}_{1}\right)$ and the relative specific capacity $\left(\mathrm{Q}_{\mathrm{n}} / \mathrm{Q}_{\text {theoritical }}\right)$.

In this context, the $4 \mathrm{CT}-\mathrm{Naph}$ thalene has been tested doubling the amount of conductive carbon (40 wt.\% of $\mathrm{Kb}$, 10wt\% of CNT) everything else being the same. Surprisingly enough, the discharged capacity in $1 \mathrm{M} \mathrm{NaClO}_{4}$ aqueous electrolyte is virtually unchanged ( $38 \mathrm{mAh} / \mathrm{g}$ ) (Figure 8). The SEM images of this sample is compared in Figure 9 to that containing $25 \mathrm{wt}$ \% of carbon additive. The two samples distinctively show the three components of the composite electrodes. More particularly, the two mixtures show 4 CT-Naphthalene particles are nicely wrapped by nano-grains (and nano-tubes in the case of the 5owt $\%$ mixture) of the carbon additive which suggests the main cause for the relatively low specific capacity of ${ }_{4} \mathrm{CT}$ Naphthalene is not related to insulated grains but rather to kinetic hindrance. The size of $4 \mathrm{CT}$-Naphthalene grains and quality of the carbon additive/active grain mixture could be modified by using an alternative protocol to prepare the electrode. The latter consists in co-precipitating a DMSO solution of ${ }_{4} \mathrm{CT}$-Naphthalene containing $25 \mathrm{wt} \%$ of carbon additive in water (see Experimental part for more details).
SEM images of the corresponding electrode mixture show that carbon particles leave this time some un-covered active material grains (Figure 9). As a result, only $29 \mathrm{mAh} / \mathrm{g}$ could be attained with this type of electrode which is approx. 25\% lower than with the two other electrode mixtures (Figure 8). Complementary images taken at lower magnifications (Figure $\mathrm{S}_{13}$ ) reiterate these observations and highlight that in all cases most $4 \mathrm{CT}$-Naphtalene grains are a few micron large. Accordingly, in an attempt to unify these results, we believe the slow kinetics of ${ }_{4} \mathrm{CT}$ Naphthalene electrodes is primarily ascribed to the low electrical conductivity of the compound. Its effect is all the more detrimental to the performance that grains are generally quite large. Therefore, the quality of the mixture with the carbon additive does improve the performance up to a certain point where the entire surface of the grains is covered (as observed with 25 wt.\% of carbon - hand mixed). It would therefore not be surprising that decreasing the grain size while achieving a kind of conducting 
coating would most likely greatly enhance the electrochemical properties of this compound. In this regard, Ketjenblack is presumably not the most appropriate carbon additive. To nail our point, we provide in the supplementary information the test of the well-known PTAm polymer using the present electrode chemistry. Results reported in Figure $\mathrm{S}_{15}$ indeed show that the maximum specific capacity that could be measured does not exceed $44 \mathrm{mAh} / \mathrm{g}$ ( $49 \%$ of the theoretical capacity). This value significantly departs from that obtained recently by Oyaizu and Nishide's group using an optimized electrode design with only $5 \mathrm{wt} . \%$ of single wall carbon nanotubes and an optimized current collector ${ }^{7}$.

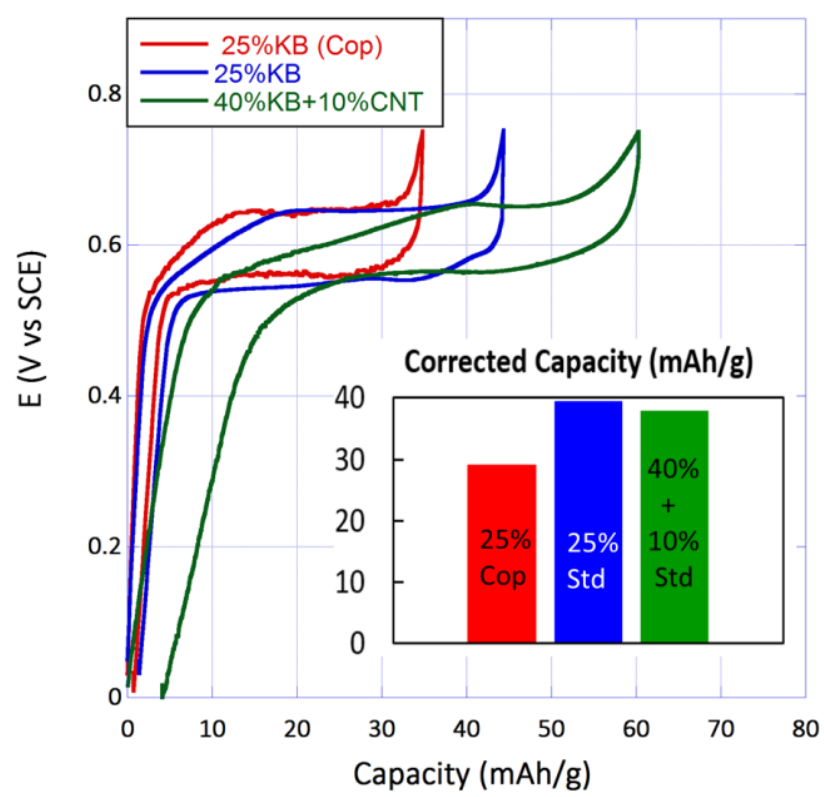

Figure 8. Galvanostatic curves of ${ }_{4} \mathrm{CT}-\mathrm{Naphthalene}$ mixed with 25 wt. $\% \mathrm{~Kb}$ (pink), 40 wt. $\% \mathrm{~Kb}+10 \% \mathrm{CNT}$ (blue) and coprecipitated with $25 \mathrm{wt} . \% \mathrm{~Kb}$ (light blue) obtained in $1 \mathrm{M}$ $\mathrm{NaClO}_{4}$ aqueous electrolyte (0.075 A/g). Inset shows the material capacity upon correction of that associated with the carbon (Figure S14). Electrodes are in the vicinity of 0.7 $\mathrm{mAh} / \mathrm{cm}^{2}$.

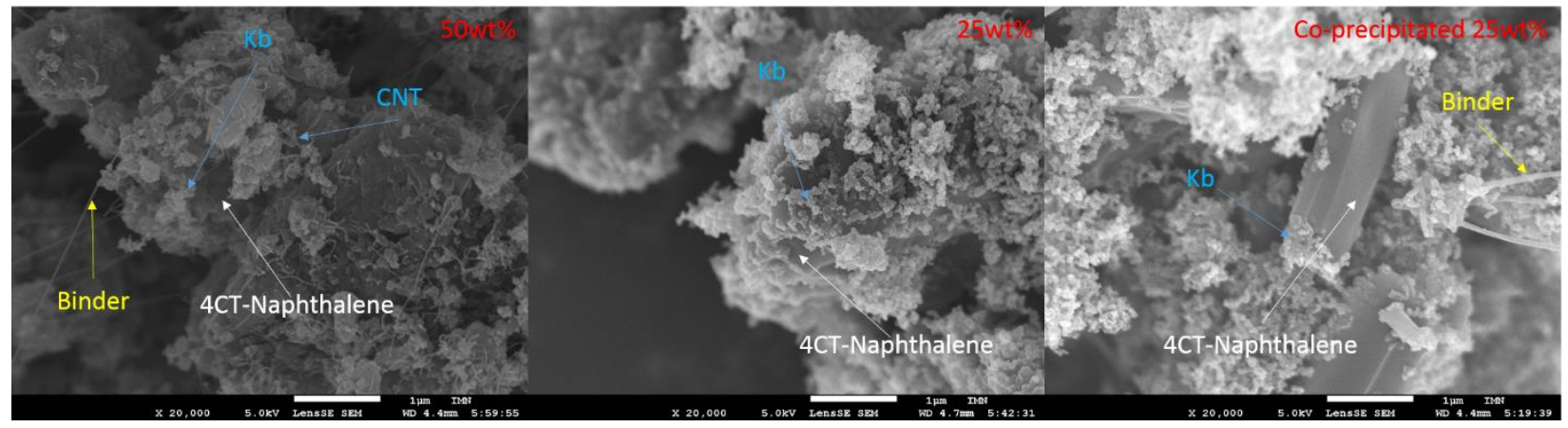

Figure 9. SEM images of ${ }_{4} \mathrm{CT}$-Naphthalene electrode mixtures with $50 \mathrm{wt} \%$ and $25 \mathrm{wt} . \%$ of conductive carbon (Ketjenblack). The co-precipitated electrode mixture with $25 \mathrm{wt}$.\% of conductive carbon is also shown.

As mentioned above, the oxidized form of the 4 HTBenzene dissolves in $1 \mathrm{M} \mathrm{NaClO}_{4}$. Accordingly, a "water-insalt" approach was evaluated using a more concentrated $\mathrm{NaClO}_{4}$ electrolyte $(8 \mathrm{M})$ without any other additives ${ }^{23}$. It seems important to remind that the price of $\mathrm{NaClO}_{4}, \mathrm{H}_{2} \mathrm{O}$ is only $1-2 \$ / \mathrm{kg}^{24}$. The material has been cycled at $0.075 \mathrm{~A} / \mathrm{g}$ in a $(0 ; 0.9) \mathrm{V}$ potential window vs SCE. Figure 10 highlights the effect of the electrolyte concentration. First, an estimation of the equilibrium potentials (defined as $\left(\mathrm{E}_{\text {eq }} \approx\right.$ $<\mathrm{E}>=\left(\mathrm{E}_{\mathrm{pa}}+\mathrm{E}_{\mathrm{pc}}\right) / 2$ ) shows the latter is $\sim 50 \mathrm{mV}$ lower in the concentrated electrolyte $(8 \mathrm{M})$ than in the $1 \mathrm{M}$ electrolyte solution which compares well with the potential difference expected from the Nernst equation (i.e., $\Delta \mathrm{E}=53 \mathrm{mV}$ ). Second, the cyclability and Coulombic efficiency of the mate- rial are significantly improved in the concentrated electrolyte. Indeed, the initial capacity is nearly the same than in the $1 \mathrm{M}$ electrolyte but remarkably, it increases a bit from $52 \mathrm{mAh} / \mathrm{g}$ to nearly $60 \mathrm{mAh} / \mathrm{g}$ ( $62 \%$ of the theoretical capacity) during the first 30 cycles and is then constant for the next 70 cycles (123 hours in total). Notwithstanding, as shown by the Ragone plot in Figure 1oc only $64 \%$ of the theoretical capacity could be achieved even at a $\mathrm{C} / 10$ rate. In conclusion, despite a higher concentration of the electrolyte solves the cyclability issue, the specific capacity of ${ }_{4}$ HT-Benzene is still hindered.

To gain a better understanding of the $4 \mathrm{HT}$-Benzene redox behavior in concentrated $\mathrm{NaClO}_{4}$ electrolyte (8M), electrochemical impedance spectroscopy (EIS) measurements 
have been performed at different states of charge using a sample containing $10 \mathrm{wt} \%$ of carbon additive (Figure 11a,b). This relatively low carbon content is used to exacerbate the electrical response associated with the material itself. Except for the spectrum corresponding to the initial state, all EIS spectra measured during the electrochemical process show a semicircle followed by a diffusion and capacitive part (Figure 11 and S16). The significant change between partially charged and initial states indicates the resistance associated with the semicircle can be confidently ascribed to a charge transfer process. Interestingly, results show the charge transfer resistance ( $36 \mathrm{Ohms}$ ) is almost stable all along the electrochemical reaction. Consistently, no effect of the ratio between the nitroxide and oxoammonium forms is observed. Most importantly, this relatively low value of the charge transfer resistance suggests that ${ }_{4} \mathrm{HT}$ -
Benzene is not an insulating material. However, the decrease of the carbon content to $10 \%$ does reduce significantly the capacity to only $11 \mathrm{mAh} / \mathrm{g}$, that is $82 \%$ lower than with $25 \mathrm{wt}$ \% (Figure $11 \mathrm{c}, \mathrm{d}$ ), therefore suggesting a strong impact of the percolating network. In this regard, the EIS results suggest that the low experimental capacity could be attributed to the low conductivity between the material grains hampering electron feeding between particles. This assertion is also supported by the trend of the charge transfer resistance that scales almost linearly with the inverse of the specific capacity (Figure 11c) and therefore with the number of connected grains. Accordingly, the full capacity (97 mAh/g) could be achieved with 40 wt.\% of Ketjenblack and $10 \mathrm{wt} . \%$ of CNT hand mixed with the material (Figure 11d). As a result, both TEMPO derivatives (4HTBenzene and ${ }_{4} \mathrm{CT}$-Naphthalene) suffer from kinetic hindrance that inhibits the performance.
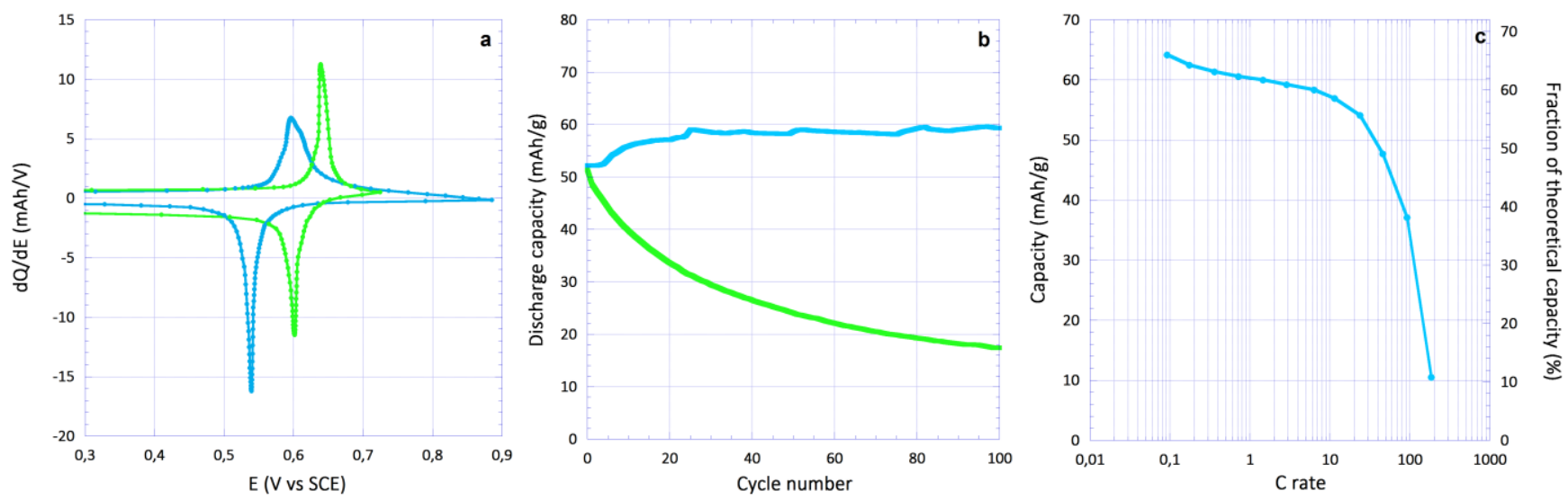

Figure 10. a) Incremental capacity curve on cycle 4 derived from galvanostatic cycling of $4 \mathrm{HT}$-Benzene at o.o75 A/g in highly concentrated $8 \mathrm{M}$ (blue) and $1 \mathrm{M}$ (green) $\mathrm{NaClO}_{4}$; b) cyclability of $4 \mathrm{HT}$-Benzene at $0.075 \mathrm{~A} / \mathrm{g}$ in $8 \mathrm{M}$ (blue) and $1 \mathrm{M}$ (green) $\mathrm{NaClO}$; c) Ragone plot of $4 \mathrm{HT}$-Benzene in $8 \mathrm{M} \mathrm{NaClO}_{4}$. Electrodes contain $25 \mathrm{wt} \%$ of carbon additive and are in the vicinity of $0.7 \mathrm{mAh} / \mathrm{cm}^{2}$. 

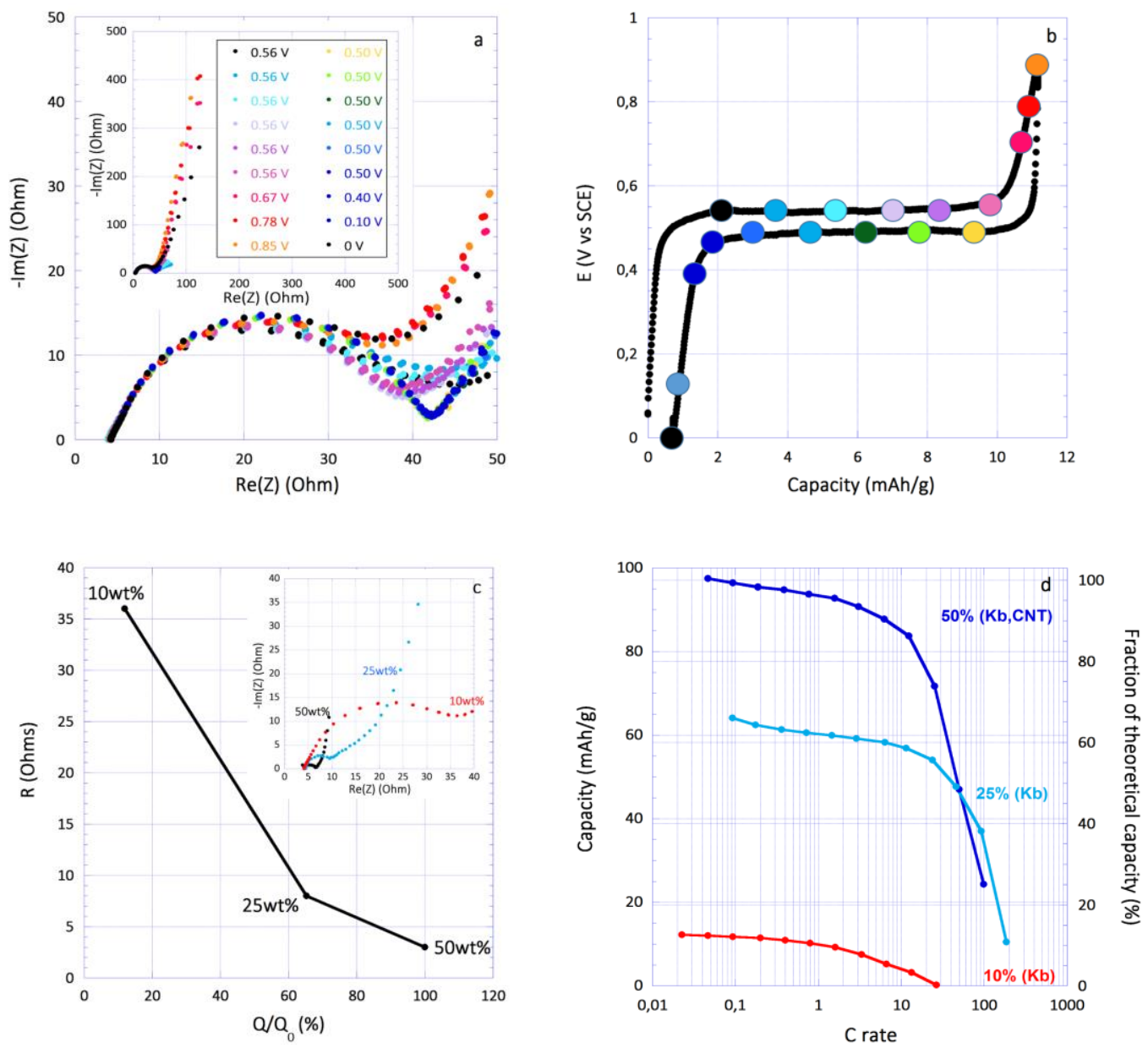

Figure 11. a) EIS measurements performed at different states of charge using a sample of $4 \mathrm{HT}$-Benzene containing $10 \mathrm{wt} \%$ of carbon additive in $8 \mathrm{M} \mathrm{NaClO}_{4}$; b) Galvanostatic curve of the $4 \mathrm{HT}$-Benzene $\left(0.7 \mathrm{mAh} / \mathrm{cm}^{2}\right)$ electrode containing $10 \mathrm{wt} \%$ of carbon additive in $8 \mathrm{M} \mathrm{NaClO}_{4}$; c) Dependence of charge transfer resistance towards the specific capacity (the capacity has been normalized to the theoretical capacity (Qo); inset of c) EIS measurements performed at the end of charge of samples of ${ }_{4} \mathrm{HT}$-Benzene containing $50 w t \%, 25 w t \%$ and $10 w t \%$ of conductive carbon; d) Ragone plot of 4 HT-Benzene electrodes containing 50wt $\%$, 25wt $\%$ and $10 w t \%$ of conductive carbon.

To curtail the impact (mass and cost) of the concentrated $\mathrm{NaClO}_{4}$ electrolyte at the cell level, a 4 HT-Benzene thick electrode of $7.8 \mathrm{mAh} / \mathrm{cm}^{2}\left(80 \mathrm{mg} / \mathrm{cm}^{2} ; 1.10 \mathrm{~mm}\right)$ areal $\mathrm{ca}-$ pacity was designed and evaluated (Figure 12). During the first 68 cycles, the capacity sharply rises from 22 to $40 \mathrm{mAh} / \mathrm{g}$ which most likely mirrors an activation process associated with the wetting of the electrode porosity. The latter can be mitigated however, by applying a floating period at the end of the charge $(0.9 \mathrm{~V})$ until the current drops to $0.015 \mathrm{~A} / \mathrm{g}(\mathrm{C} / 5)$ (Figure 12a and $\mathrm{S} 17$ ). With that condition, the discharged capacity slightly increases up to $66 \mathrm{mAh} / \mathrm{g}_{4} \mathrm{HT}$-Benzene or $5.3 \mathrm{mAh} / \mathrm{cm}^{2}$ (68\% of the theoretical capacity) after 535 cycles ( 38 days). The Coulombic efficiency also increases during the first 30 cycles to stabilize at $99.8 \%$, suggesting an important contribution of the oxygen evolution in the initial stages. A blank electrode containing only the conductive additive indicates that half of the irreversibility actually stems from side reactions going on at the surface of the carbon (Figure S18). The latter sensibly attenuate with cycling presumably due to the increasing acidity of the electrolyte from neutral $\mathrm{pH}$ to $\mathrm{pH}=4$ after 25 cycles (Figure 12b). Remarkably, the power properties of the thick electrode are not strongly impacted up to C-rate as it merely behaves like the thin ones (Figure 12C). This therefore also serves to reiterate that performance are limited by the efficiency of the electrode chemistry in coping for the low conductivity of the material. 

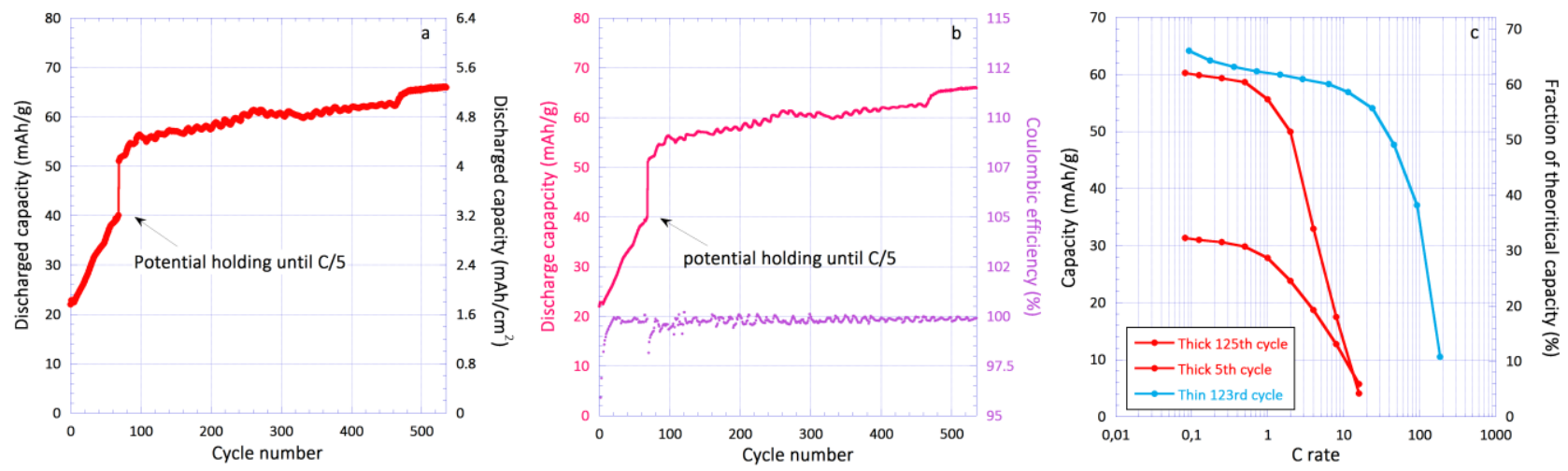

Figure 12. a) Cyclability of $4 \mathrm{HT}$-Benzene in $8 \mathrm{M} \mathrm{NaClO}_{4}$ aqueous electrolyte $\left(8 \mathrm{o} \mathrm{mg} / \mathrm{cm}^{2}\right)$; b) corresponding cyclability and coulombic efficiency together with c) Ragone plots of both thin $\left(10 \mathrm{mg} / \mathrm{cm}^{2}\right)$ and thick electrodes $\left(80 \mathrm{mg} / \mathrm{cm}^{2}\right)$.

Although no further attempts have been done to improve the overall kinetics of the electrodes, a full cell has been evaluated with thick electrodes (mixed with $25 \mathrm{wt} . \%$ of Ketjenblack) by coupling the 4 HT-Benzene positive electrode to a novel bipyridinium-naphthalene diimide oligomer (referred to as $\mathrm{DNVBr}$ ) as the negative one. The formula and synthesis of DNVBr are provided in the supplementary information. As demonstrated in our previous work for a molecule of the same family ${ }^{25}$ and illustrated in schema $\mathrm{S}, \mathrm{DNVBr}$ is a $\mathrm{p}$ and $\mathrm{n}$ type active material that releases anions and uptakes cation simultaneously during its electrochemical reduction (charge of the full cell). The present ${ }_{4} \mathrm{HT}$-Benzene/DNVBr full cell is therefore a mixed, rocking-chair anionic ${ }^{12,26}$ cell (that corresponds on charge to the transfer of anions from DNVBr to 4 HT-Benzene) and a dual-ion 5 one simultaneously (with the transfer on charge of cations from the electrolyte to $\mathrm{DNVBr}$ and corresponding anions to the $4 \mathrm{HT}$-Benzene). Although a detailed study of the electrochemical performance of the DNVBr compound is out of the scope of the present paper, its charge-discharge profile and specific capacity retention are provided in Figure S19 for an $80 \mathrm{mg} / \mathrm{cm}^{2}$ electrode. The capacity ratio $4 \mathrm{HT}$-Benzene:DNVBr leading to the highest energy density was found to be 0.99 and the areal capacity of both electrodes was approx. $8 \mathrm{mAh} / \mathrm{cm}^{2}$ (see Experimental part for more details regarding the electrode preparation). For the sake of comparison, an identical full cell but using thin electrodes of $0.7 \mathrm{mAh} / \mathrm{cm}^{2}\left(10 \mathrm{mg} / \mathrm{cm}^{2}\right.$ electrodes) has also been evaluated. The cell has been cycled at $0.075 \mathrm{~A} / \mathrm{g}(\mathrm{1C})$ within a controlled voltage of $(0 ; 1.8) \mathrm{V}$ vs. SCE (Figure 13a, b) by holding the end-of-charge potential until $0.015 \mathrm{~A} / \mathrm{g}(\mathrm{C} / 5)$. Under these conditions, an average voltage of $0.96 \mathrm{~V}$ was obtained with a remarkably flat specific capacity of $30 \mathrm{mAh} / \mathrm{g}_{\text {active materials }}$ associated with an excellent Coulombic efficiency (99.6\%) over 285 hours ( 12 days, 190 cycles) (Figure 13b). These results compare well with that achieved with the thin electrode full cell while allowing much higher areal capacity of $4.6 \mathrm{mAh} / \mathrm{cm}^{2}$ (vs $0.7 \mathrm{mAh} / \mathrm{cm}^{2}$ for the thin one). Remarkably such a high areal capacity competes well up to 8C (Figure 13d). We note the slightly reduced discharge voltage arises from a higher polarization associated with the thick electrodes (Figure 13a). In addition is worth noting that although a high maximum charge voltage of $1.8 \mathrm{~V}$ is applied, self-pH-buffering of the electrolyte occurs to around $\mathrm{pH}=7$, thus mitigating current collector corrosion. The specific energy density of this non-optimized thick electrode cell is $28 \mathrm{Wh} / \mathrm{kg}$ per mass of both active materials at C-rate and $35 \mathrm{Wh} / \mathrm{kg}$ at $\mathrm{C} / 8$ rate, the latter rate being still acceptable for stationary storage. This $4 \mathrm{HT}-$ Benzene//DNVBr cell is the first full organic cell with close to millimeter thick electrodes to the best of our knowledge. In comparison, the specific energy density obtained for the thin electrode cell saturates to approx. the same value of $36 \mathrm{Wh} / \mathrm{kg}$ at $\mathrm{C}$ and $\mathrm{C} / 2$ rates. However, extrapolating these results to a whole stack cell with electrodes of more than $700 \mathrm{~cm}^{2}$, shows that the lower fraction of inactive components inherent to the use of millimeter thick electrodes enables $13.6 \mathrm{Wh} / \mathrm{kg}_{\text {stack }}$ at $1 \mathrm{C}$ and $17.4 \mathrm{Wh} / \mathrm{kg}_{\text {stack }}$ at $\mathrm{C} / 8$, which represents gains of nearly $13 \%$ and $37 \%$ respectively, vs. the same cell but having $0.7 \mathrm{mAh} / \mathrm{cm}^{2}$ electrodes (12.7 Wh/ $\mathrm{kg}_{\text {stack }}$ ) (Figure $13 \mathrm{c}, \mathrm{d}$ ) (see supplementary information for details regarding calculations). 
In the light of these results, pouch cell configurations with similar thick electrodes have also been evaluated to further demonstrate the practicability of the present full organic aqueous battery (see Experimental part for further details). The capacity ratio $4 \mathrm{HT}$-Benzene: $\mathrm{DNVBr}$ was set to 1.o1. In these conditions, an average output voltage of $0.78 \mathrm{~V}$ was obtained with similar areal capacity $\left(4.5 \mathrm{mAh} / \mathrm{cm}^{2}\right.$ corresponding to $30 \mathrm{mAh} / \mathrm{g}_{\text {active materials }}$ ), high cyclability ( $98 \%$ of capacity retention after 500 hours), Coulombic efficiency (99.6\%) at 0.075 A/g (Figure 14a) and rate capability (Figure 14b). More interestingly, an even higher areal capacity $\left(5 \mathrm{mAh} / \mathrm{cm}^{2}\right)$ has been further attained at $0.009 \mathrm{~A} / \mathrm{g}(\mathrm{C} / 8)$.
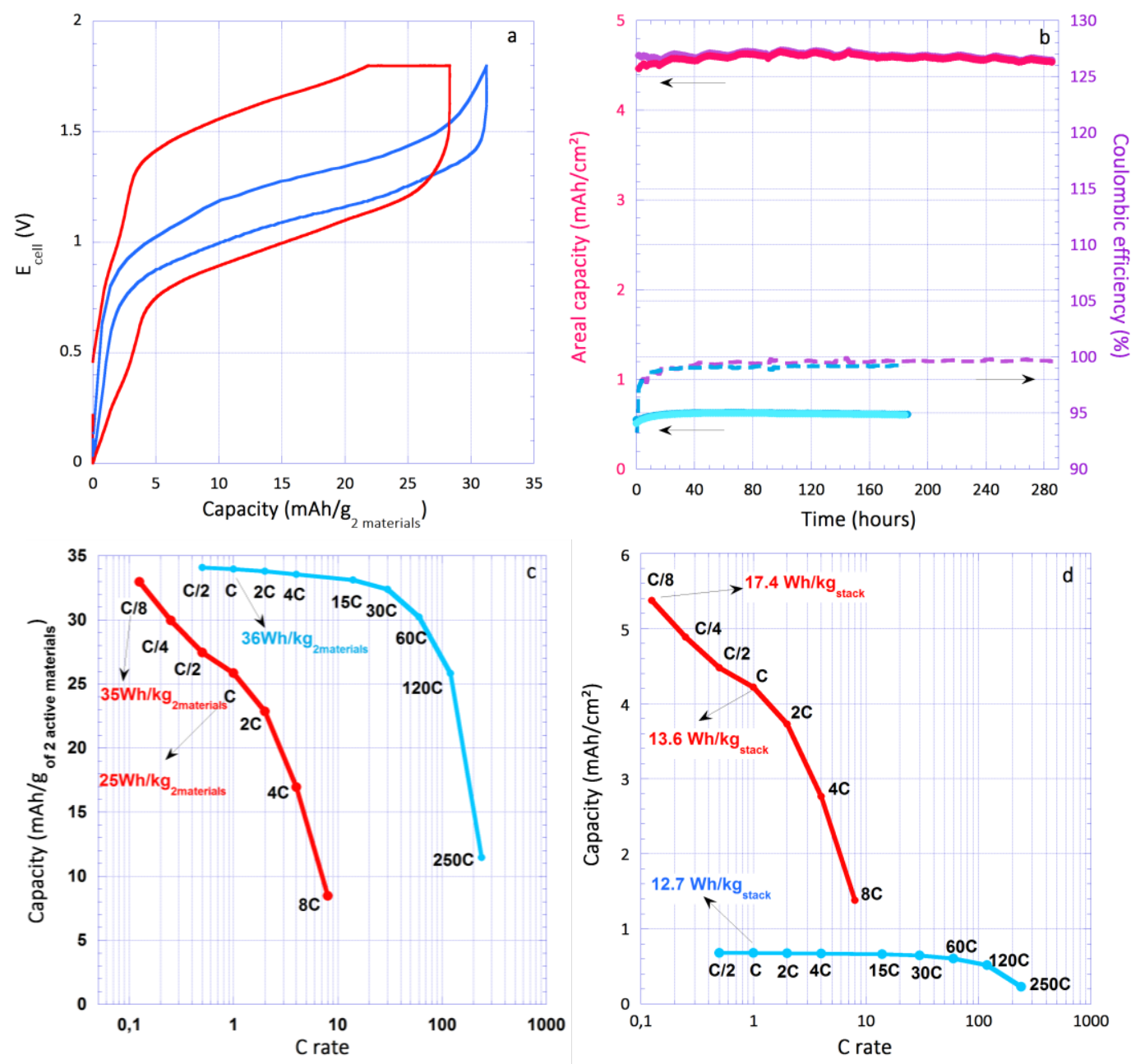

Figure 13. a) Cell voltage ( $\left.E_{\text {cell }}\right)$-capacity profile of full cells of 0.7 (blue) and $8 \mathrm{mAh} / \mathrm{cm}^{2}$ (red) electrodes at $0.075 \mathrm{~A} / \mathrm{g}$, b) Cyclability of the full cells (violet thick electrodes full cell; blue thin electrodes full cell) at $0.075 \mathrm{~A} / \mathrm{g}$ along with Coulombic efficiency; c, d) corresponding Ragone plots in $8 \mathrm{M} \mathrm{NaClO}_{4}$. 

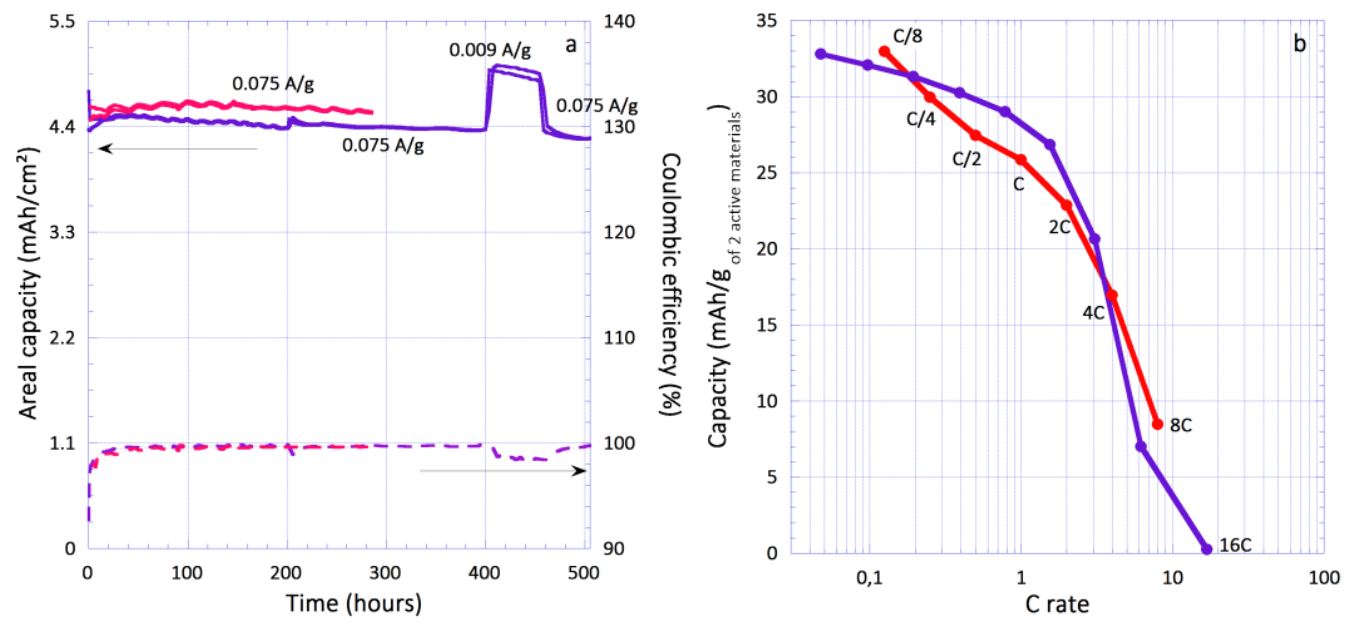

Figure 14. a) Cyclability of the full cells (violet pouch cell; red glass cell) along with Coulombic efficiency in $8 \mathrm{M} \mathrm{NaClO}_{4}$; c, d) corresponding Ragone plots.

\section{Conclusion}

All the above results serve to demonstrate and rationalize the potentialities and limitations of two small TEMPO molecules in neutral molar aqueous electrolyte. For the first the commercially available 4-hydroxy TEMPO benzoate molecule has been proved to be highly efficient active material in millimeter thick electrodes delivering up to 5.3
$\mathrm{mAh} / \mathrm{cm}^{2}$ at $\mathrm{C}$ rate for over 500 cycles in neutral and cheap $8 \mathrm{M} \mathrm{NaClO}_{4}$ electrolyte. Paired with a new bipyridiniumnaphthalene diimide oligomer a novel type of aqueous battery that operates simultaneously in anion-rocking chair and dual-cation/anion mode is demonstrated. The full cell shows excellent cyclability and Coulombic efficiency offering $35 \mathrm{Wh} / \mathrm{kg}_{\text {materials }}$ on discharge at $\mathrm{C} / 8$. We believe these results represent an important advance towards cheaper and more sustainable energy storage systems. 


\section{ASSOCIATED CONTENT}

Supporting Information. Further electrochemical details and all the materials' characterizations could be found in the Supporting Information. This material is available free of charge via the Internet at http://pubs.acs.org.

\section{AUTHOR INFORMATION}

\section{Corresponding Author}

* Fabrice Odobel Fabrice.Odobel@univ-nantes.fr

* Philippe Poizot philippe.poizot@cnrs-imn.fr

* Joël Gaubicher Joel.Gaubicher@cnrs-imn.fr

\section{Author Contributions}

All authors have given approval to the final version of the manuscript.

\section{ACKNOWLEDGMENT}

The authors would like to thank Dr. Olivier Crosnier (IMN) for his constant technical assistance with operando XRD experiments, and with Dr. Magali Allain from the University of Angers for her important help regarding the single crystal structural resolution.

\section{REFERENCES}

(1) Lithium Process Chemistry: Resources, Extraction, Batteries, and Recycling; Chagnes, A., Swiatowska, J., Eds.; Elsevier: Amsterdam Boston Heidelberg, 2015.

(2) Suo, L.; Borodin, O.; Sun, W.; Fan, X.; Yang, C.; Wang, F.; Gao, T.; Ma, Z.; Schroeder, M.; von Cresce, A.; et al. Advanced High-Voltage Aqueous Lithium-Ion Battery Enabled by "Water-inBisalt" Electrolyte. Angew. Chem. Int. Ed. 2016, 55 (25), 7136-7141.

(3) Yamada, Y.; Yamada, A. Superconcentrated Electrolytes to Create New Interfacial Chemistry in Non-Aqueous and Aqueous Rechargeable Batteries. Chem. Lett. 2017, 46 (8), 10561064.

(4) Wang, F.; Suo, L.; Liang, Y.; Yang, C.; Han, F.; Gao, T.; Sun, W.; Wang, C. Spinel LiNi0.5Mn1.504 Cathode for High-Energy Aqueous Lithium-Ion Batteries. Adv. Energy Mater. 2017, 7 (8), 1600922.

(5) Dong, X.; Yu, H.; Ma, Y.; Bao, J. L.; Truhlar, D. G.; Wang, Y.; Xia, Y. All-Organic Rechargeable Battery with Reversibility Supported by "Water-in-Salt" Electrolyte. Chem. - Eur. J. 2017, 23 (11), 2560-2565.

(6) Chikushi, N.; Yamada, H.; Oyaizu, K.; Nishide, $\mathrm{H}$. TEMPO-Substituted Polyacrylamide for an Aqueous Electrolyte-Typed and Organic-Based
Rechargeable Device. Sci. China Chem. 2012, 55 (5), 822-829.

Hatakeyama-Sato, K.; Wakamatsu, H.; Katagiri, R.; Oyaizu, K.; Nishide, H. An Ultrahigh Output Rechargeable Electrode of a Hydrophilic Radical Polymer/Nanocarbon Hybrid with an Exceptionally Large Current Density beyond $1 \mathrm{~A}$ $\mathrm{Cm}^{-2}$. Adv. Mater. 2018, 30, 1800900.

(8) Koshika, K.; Sano, N.; Oyaizu, K.; Nishide, H. An Aqueous, Electrolyte-Type, Rechargeable Device Utilizing a Hydrophilic Radical PolymerCathode. Macromol. Chem. Phys. 2009, 210 (22), 1989-1995.

(9) Koshika, K.; Sano, N.; Oyaizu, K.; Nishide, H. An Ultrafast Chargeable Polymer Electrode Based on the Combination of Nitroxide Radical and Aqueous Electrolyte. Chem Commun 2009, No. 7, 836-838.

(10) Suga, T.; Konishi, H.; Nishide, H. Photocrosslinked Nitroxide Polymer Cathode-Active Materials for Application in an Organic-Based $\mathrm{Pa}$ per Battery. Chem. Commun. 2007, No. 17, 1730-1732.

(11) Itoi, H.; Hasegawa, H.; Iwata, H.; Ohzawa, Y. Non-Polymeric Hybridization of a TEMPO Derivative with Activated Carbon for High-Energy-Density Aqueous Electrochemical Capacitor Electrodes. Sustain. Energy Fuels 2018, 2 (3), 558-565.

(12) Koshika, K.; Chikushi, N.; Sano, N.; Oyaizu, K.; Nishide, H. A TEMPO-Substituted Polyacrylamide as a New Cathode Material: An Organic Rechargeable Device Composed of Polymer Electrodes and Aqueous Electrolyte. Green Chem. 2010, 12 (9), 1573-1575.

(13) Suga, T.; Pu, Y.-J.; Oyaizu, K.; Nishide, H. Electron-Transfer Kinetics of Nitroxide Radicals as an Electrode-Active Material. Bull. Chem. Soc. Jpn. 2004, 77 (12), 2203-2204.

(14) Itoi, H.; Hasegawa, H.; Iwata, H.; Ohzawa, Y. Non-Polymeric Hybridization of a TEMPO Derivative with Activated Carbon for High-Energy-Density Aqueous Electrochemical Capacitor Electrodes. Sustain. Energy Fuels 2018, 2 (3), 558-565.

(15) Ji, X.; Lee, K. T.; Nazar, L. F. A Highly Ordered Nanostructured Carbon-Sulphur Cathode for Lithium-Sulphur Batteries. Nat. Mater. 2009, 8 (6), 500-506. 
(16) Lepage, D.; Michot, C.; Liang, G.; Gauthier, M.; Schougaard, S. B. A Soft Chemistry Approach to Coating of LiFePO4 with a Conducting Polymer. Angew. Chem. Int. Ed Engl. 2011, 50 (30), 6884-6887.

(17) Pang, X.; Wang, H.; Ran Zhao, X.; Jun Jin, W. Anionic 3D Cage Networks Self-Assembled by lodine and V-Shaped Pentaiodides Using Dimeric Oxoammonium Cations Produced in Situ as Templates. Dalton Trans. 2013, 42 (24), 8788-8795.

(18) Pang, X.; Zhao, X. R.; Wang, H.; Sun, H.-L.; Jin, W. J. Modulating Crystal Packing and Magnetic Properties of Nitroxide Free Radicals by Halogen Bonding. Cryst. Growth Des. 2013, 13 (8), 3739-3745.

(19) Leriche, J. B.; Hamelet, S.; Shu, J.; Morcrette, M.; Masquelier, C.; Ouvrard, G.; Zerrouki, M.; Soudan, P.; Belin, S.; Elkaïm, E.; et al. An Electrochemical Cell for Operando Study of Lithium Batteries Using Synchrotron Radiation. J. Electrochem. Soc. 2010, 157 (5), A606-A610.

(20) Ouvrard, G.; Zerrouki, M.; Soudan, P.; Lestriez, B.; Masquelier, C.; Morcrette, M.; Hamelet, S.; Belin, S.; Flank, A. M.; Baudelet, F. Heterogeneous Behaviour of the Lithium Battery Composite Electrode LiFePO4. J. Power Sources 2013, 229, 16-21.

(21) Chang, H.-H.; Chang, C.-C.; Wu, H.-C.; Yang, M.-H.; Sheu, H.-S.; Wu, N.-L. Study on Dynamics of Structural Transformation during Charge/Discharge of LiFePO4 Cathode. Electrochem. Commun. 2008, 10 (2), 335-339.

(22) Tang, M.; Huang, H.-Y.; Meethong, N.; Kao, Y.H.; Carter, W. C.; Chiang, Y.-M. Model for the
Particle Size, Overpotential, and Strain Dependence of Phase Transition Pathways in Storage Electrodes: Application to Nanoscale Olivines. Chem. Mater. 2009, 21 (8), 15571571.

(23) Pasta, M.; Wessells, C. D.; Liu, N.; Nelson, J.; McDowell, M. T.; Huggins, R. A.; Toney, M. F.; Cui, Y. Full Open-Framework Batteries for Stationary Energy Storage. Nat. Commun. 2014, 5, 3007.

(24) Sodium Perchlorate,Sodium Perchlorate Monohydrate,Blasting Industry-10 Year Gold Supply Factory Supply - Buy Sodium Perchlorate Blasting Industry,Sodium Perchlorate Monohydrate Blasting,Sodium Perchlorate Anhydrous Perchloric Acid Product on Alibaba.com //www.alibaba.com/product-detail/SodiumPerchlorate-Sodium-Perchlorate-Monohydrate-Blasting_60285442358.html (accessed Jul 9, 2018).

(25) Perticarari, S.; Sayed-Ahmad-Baraza, Y.; Ewels, C.; Moreau, P.; Guyomard, D.; Poizot, P.; Odobel, F.; Gaubicher, J. Dual Anion-Cation Reversible Insertion in a Bipyridinium-Diamide Triad as the Negative Electrode for Aqueous Batteries. Adv. Energy Mater. 2018, 8 (8), 1701988.

(26) Sano, N.; Tomita, W.; Hara, S.; Min, C.-M.; Lee, J.-S.; Oyaizu, K.; Nishide, H. Polyviologen Hydrogel with High-Rate Capability for Anodes toward an Aqueous Electrolyte-Type and Organic-Based Rechargeable Device. ACS Appl. Mater. Interfaces 2013, 5 (4), 1355-1361. 